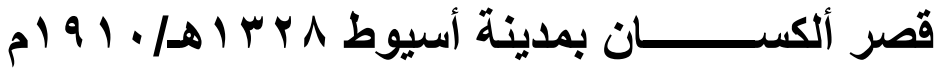 دراسة أثرية معمارية
}

أدد.مجدي عبد الجواد علوان

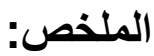

انتشر بناء العديد من القصور ذات الطرز المعمارية و الفنية المختلفة إبان حكم

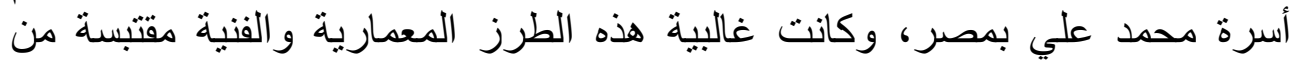

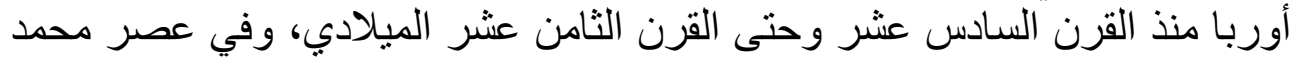

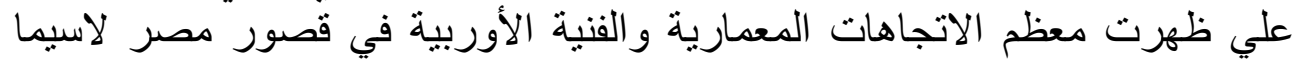
مدينتي القاهرة و الإسكندرية . معن الاتهات

و انتقلت هذه الطرز المعمارية الأوروبية إلى أقاليم مصر ومدنها.

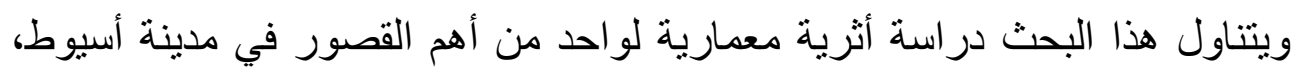

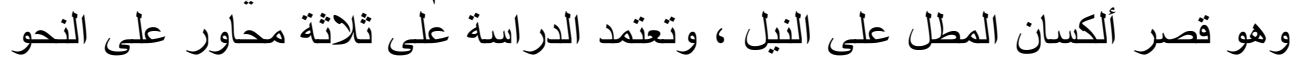
التالي : 1 : دراسة وصفية لقصر ألكسان

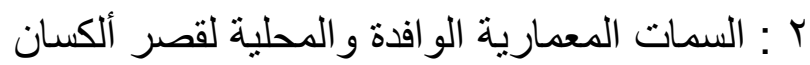
r : السمات الفنية الو افدة لقصر الكسان وسيتم تزويد البحث بعدد من المساقط الأفقية واللوحات الفوتوغر افية لإثر اء المادة العلمية.

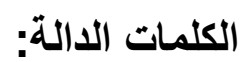
ألكسان - قصر - طر از عصر النهضة - باروك ـ الطراز القوطي - المونوجرام -

• أستاذ الآثار والعمارة الإسلامية، رئيس قسم الآثار ـ كلية الآداب - جامعة أسيوط. d magdygwady@yahoo.com 


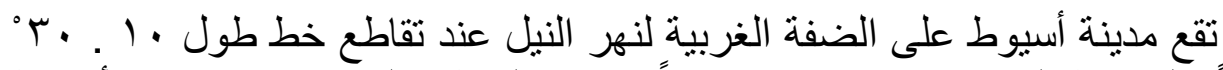

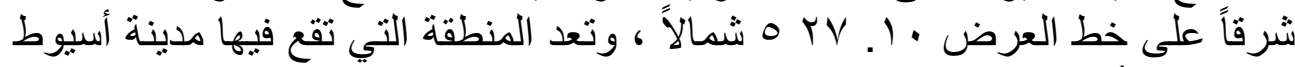

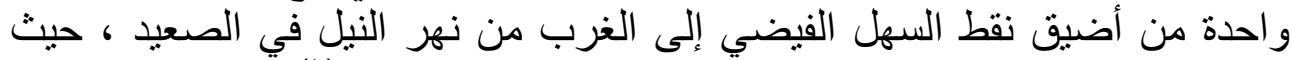
يزيد اتساع السهل الفيضي إلى الثرق من الفي الفهر عنه عن غربه (').

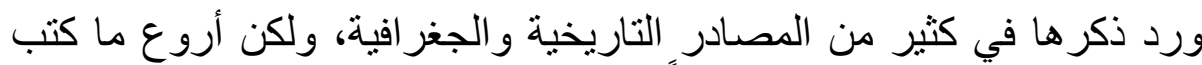

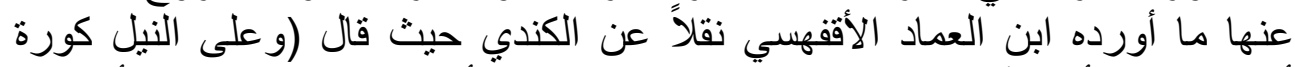

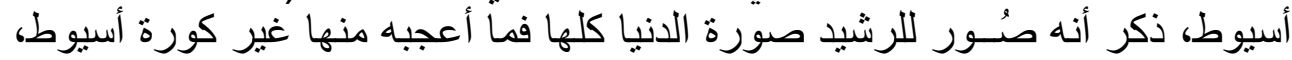

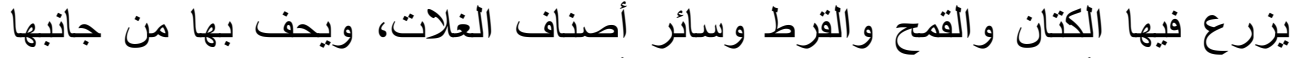

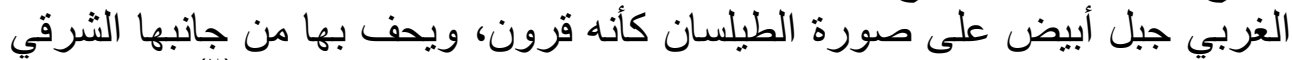

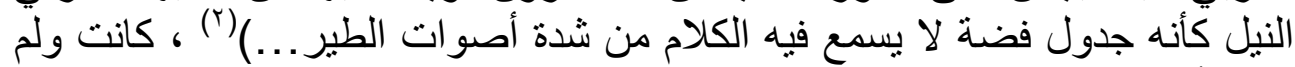

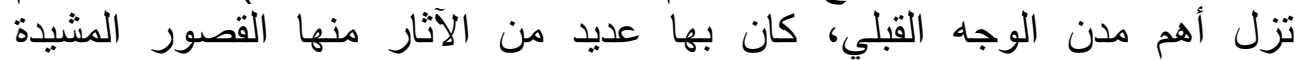

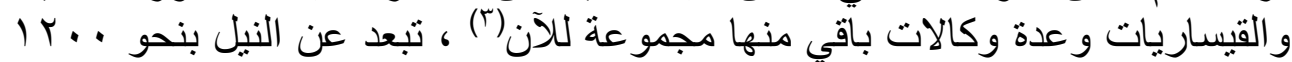

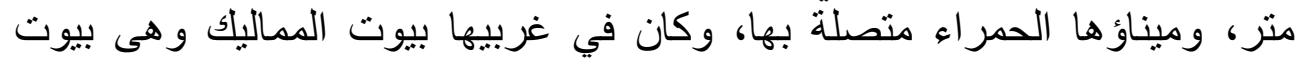

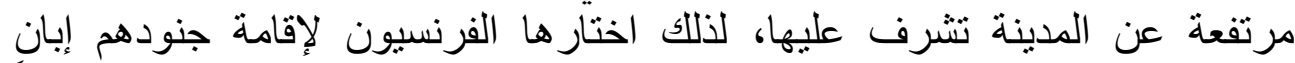

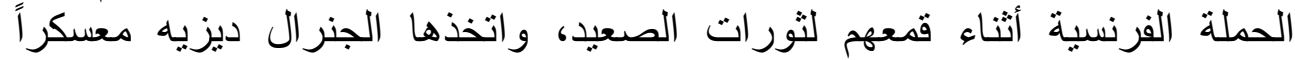

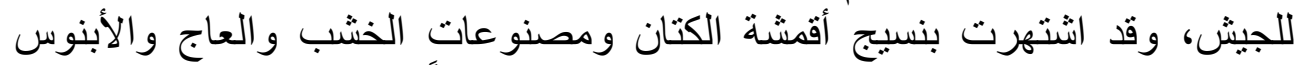

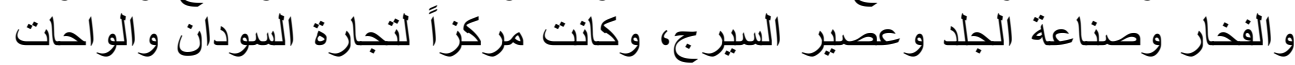

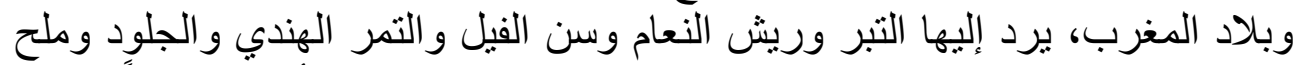

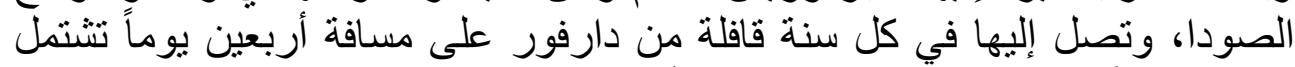

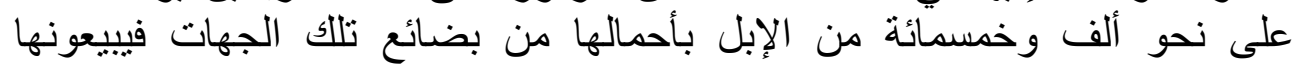
ويستبدلونها من البضائع المصرية فيحصل بذلك روائة رون عظيم لأسيوط (ء).

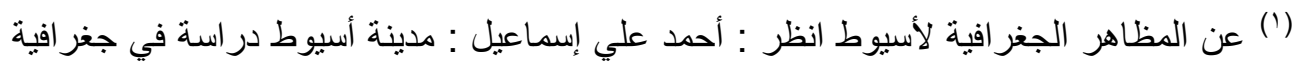

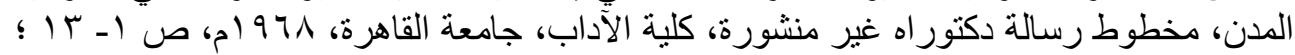

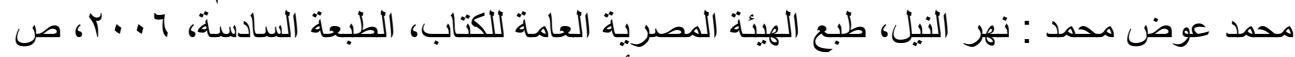

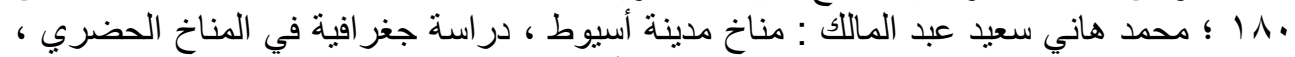

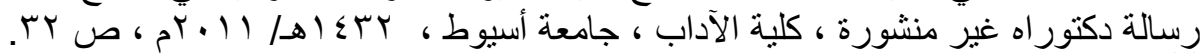

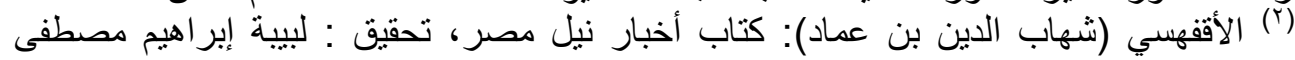

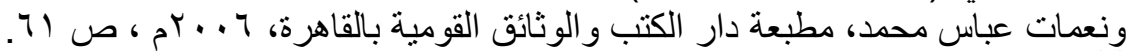

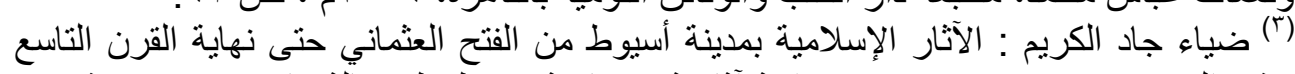

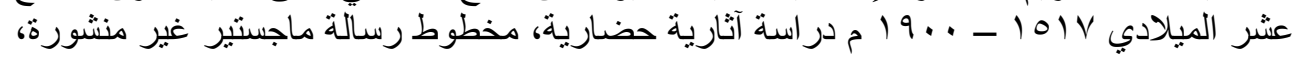

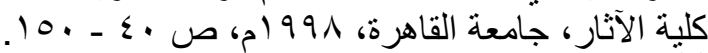

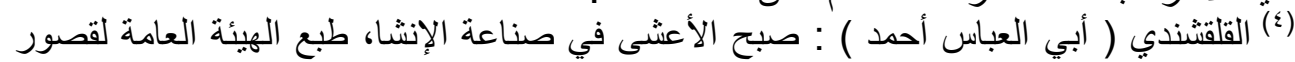

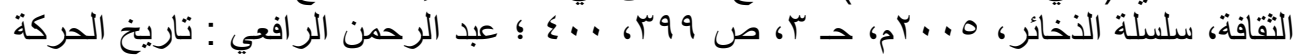

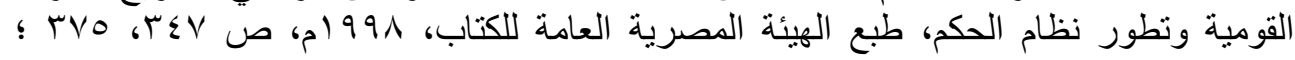




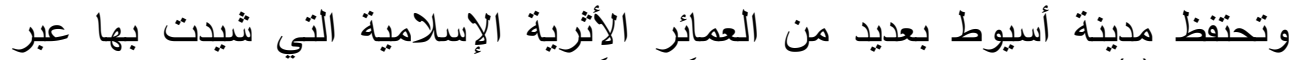

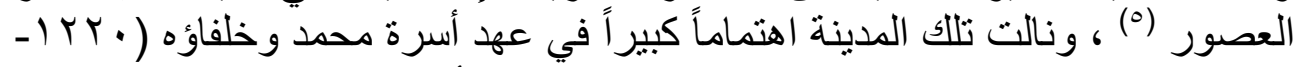

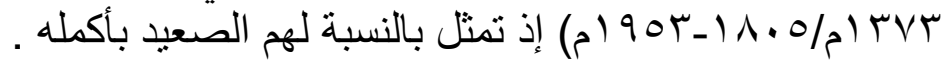

وقد شهدت مصر بأكملها نهضه معمارية في عصر محمد علي و اكبت مظاهر

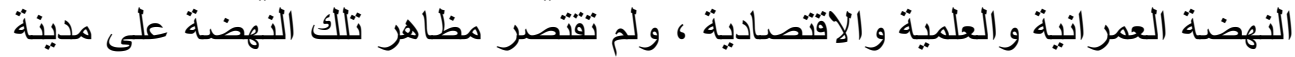

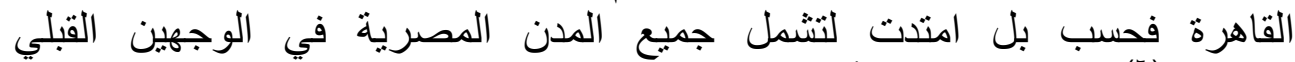
و البحري(آ) ومن بينها مدينة أسيوط.

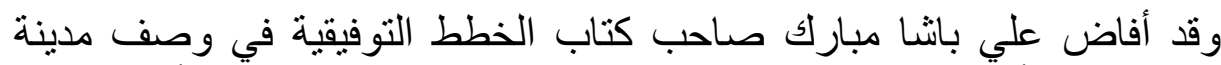

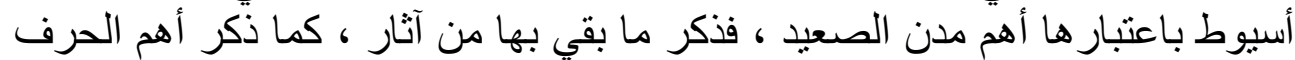

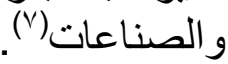

فذكر "أنها مدينة الصعيد وقصبته على الإطلاق، وهي ذات أبنية فاخرة و أكثر

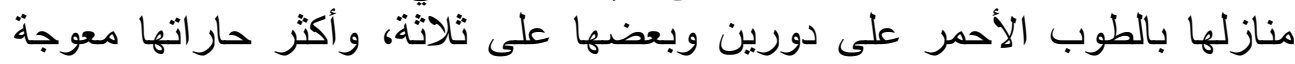

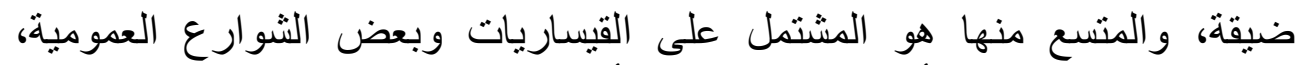

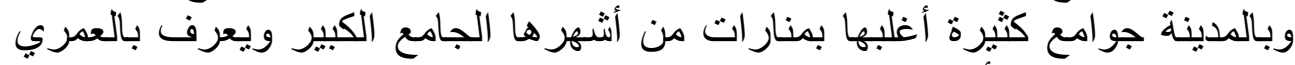

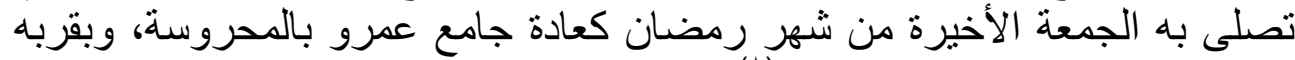

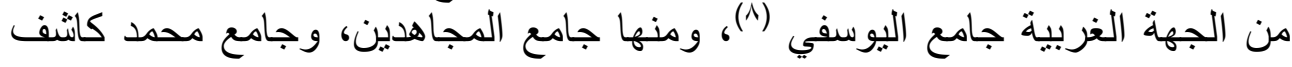

محمد رمزي : القاموس الجغرافي للبلاد المصرية، طبع الهيئة المصرية العامة للكتاب، القاهرة،

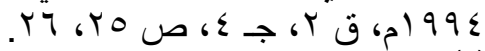

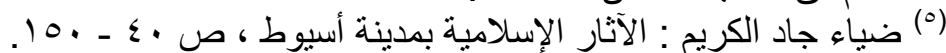

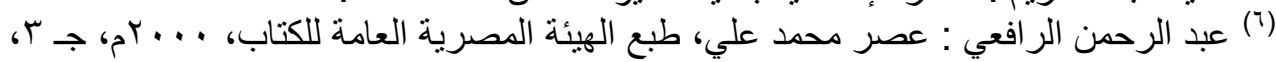
ص صا

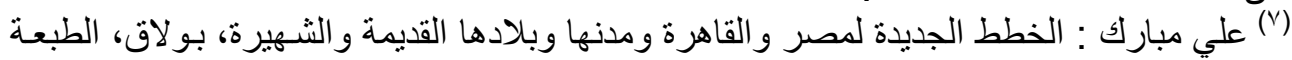

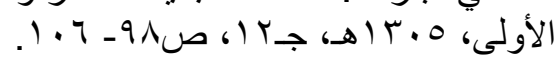

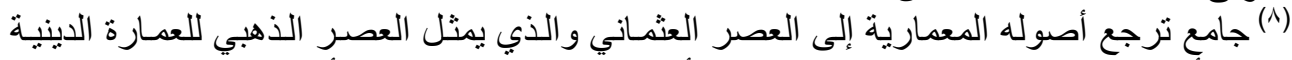

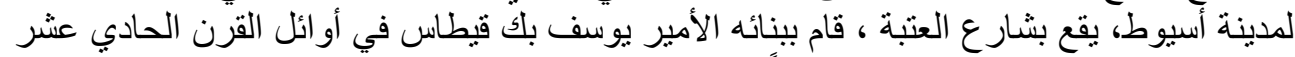

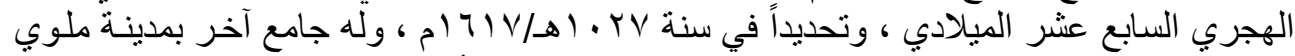

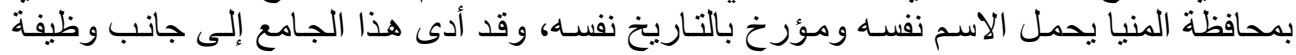

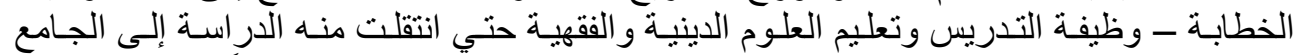

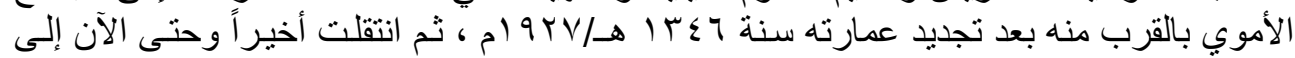

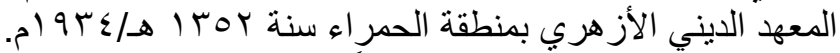

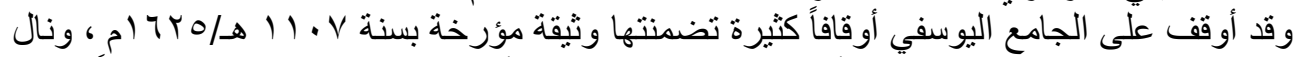

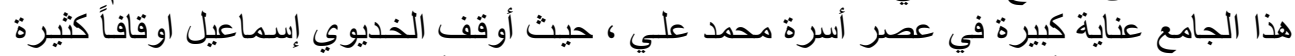

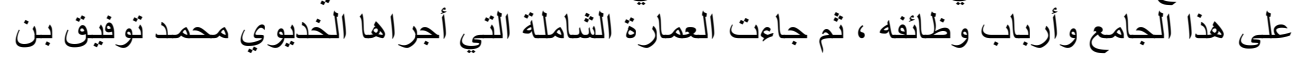

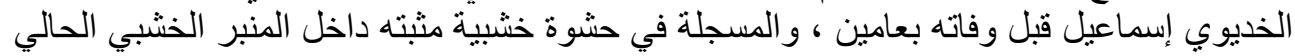
بالجامع فيما نصاء: 
بيك زاده في جهتها الثرقية، وجامع سيدي جلال الدين السيوطي وهو عامر

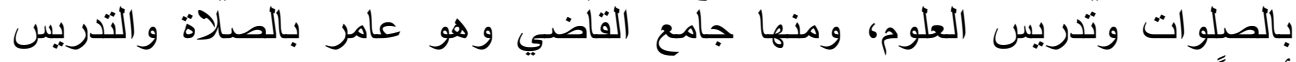

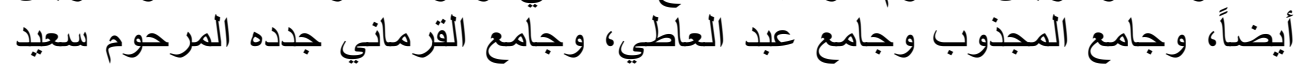
بانشا وجعل له مائة وخمسين فداناًُ الناظر عليه الآن الثنيخ الثطبي.

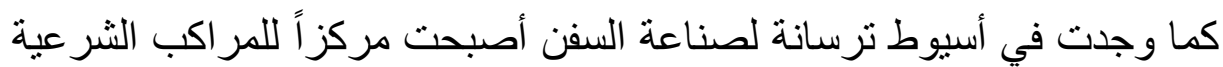

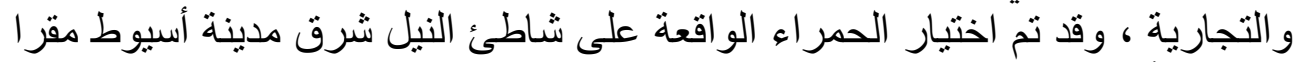

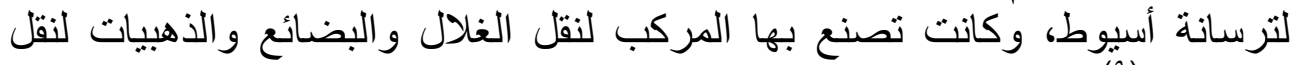
المسافرين(9)

من ناحية أخرى فقد شاركت مدينة أسيوط في تكوين ملامح الحضارة المصرية الحمبارية

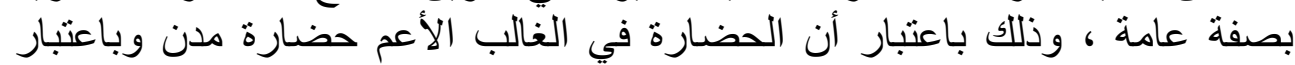

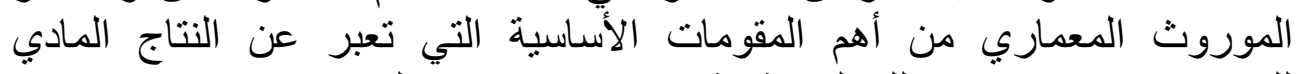
للحضارت، فقد توفرت بتلك المدينة كثير من مفردات هذاً التراث.

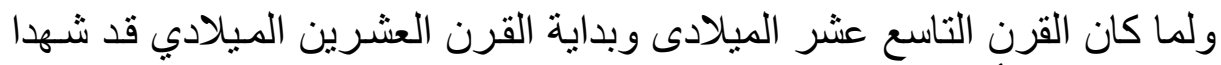

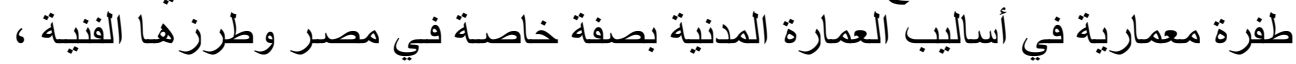

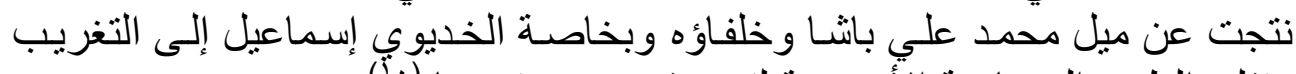

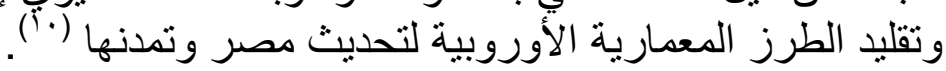

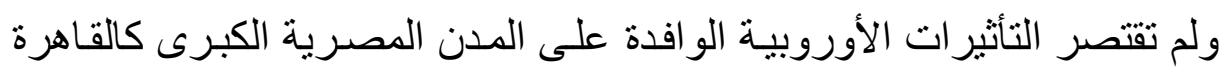

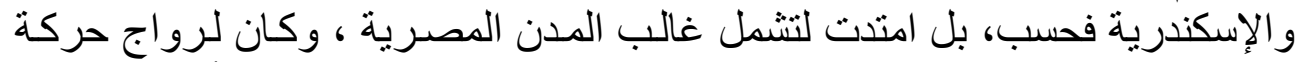

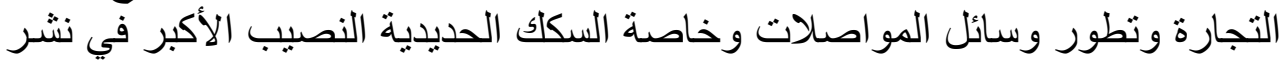

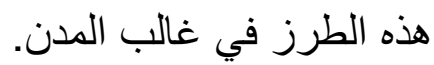

$$
\begin{aligned}
& \text { مسجد اليوسفي تم بناه وفق أمر الخديو توفيق مصر }
\end{aligned}
$$

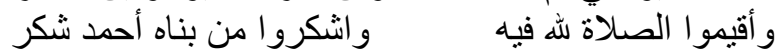

$$
\begin{aligned}
& \text {. 1199. }
\end{aligned}
$$

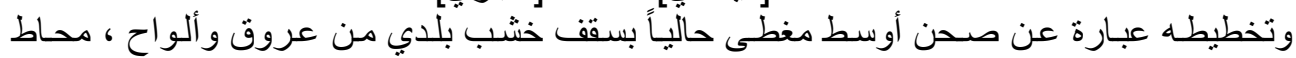

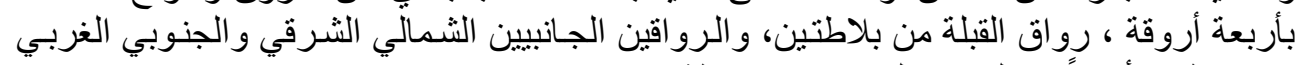

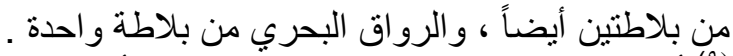

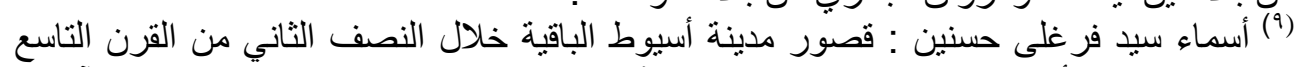

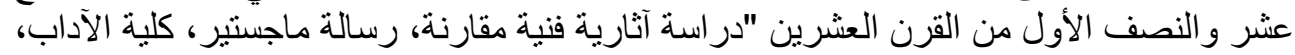

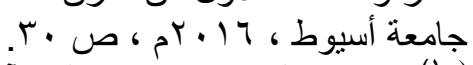
(') مجدي علوان: مقايسات المنثآت المعمارية في عصر أسرة محمد علي دراسة آثارية وثائقية

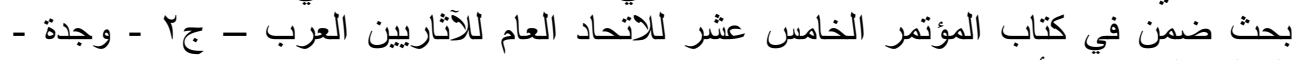

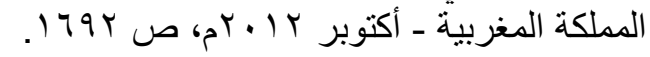




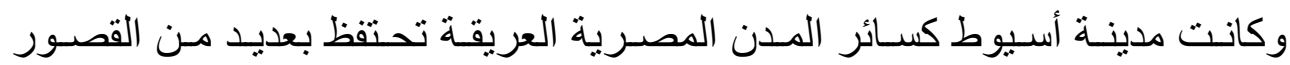

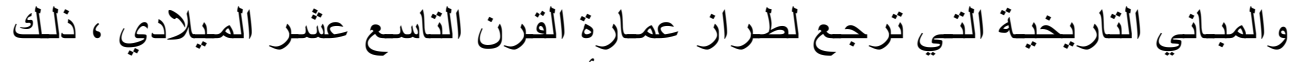

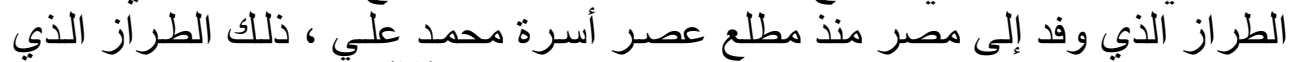

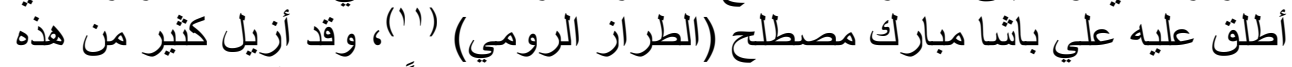

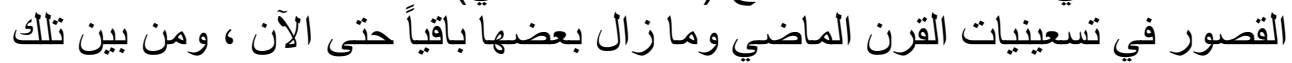
القصور الباقية ما يوضحكه

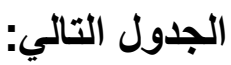

\begin{tabular}{|c|c|}
\hline 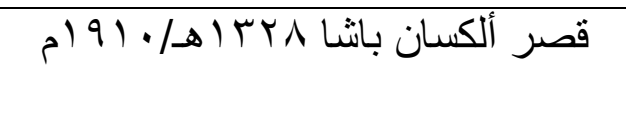 & قصر تشغله مديرية الإسكان بr آ هـ/ \\
\hline قعر حبيب باثنا دوس أه ام & قصر مسيخائيل لوقا الزق أهـ \\
\hline قصر الخواجة رزق الله حنا & 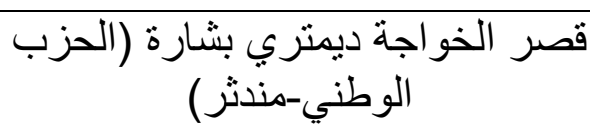 \\
\hline 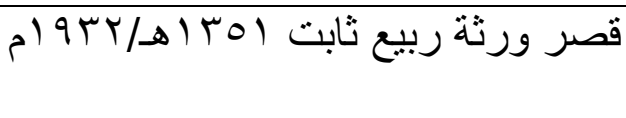 & قصر الزق الإجماعية بشار ع الجمهورية كلية الخدمة) \\
\hline
\end{tabular}

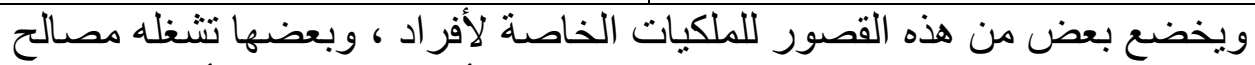

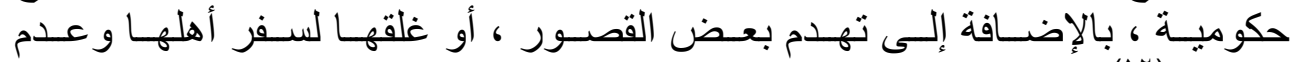

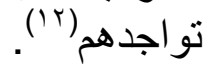

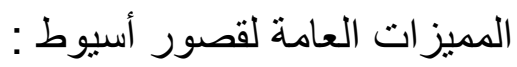
أولاً : عمائر النصف الأول من القرن التاسع عشر الميلادي: ا - البناء من طابقين في معظم الأحيان .

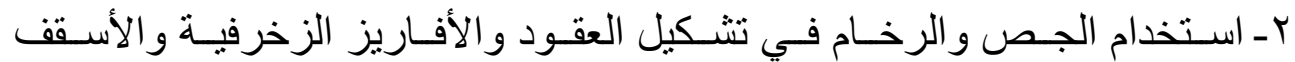

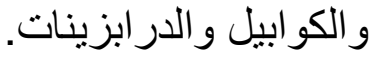

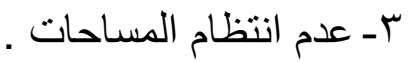
ع ـ استخدام أسلوب التمويج في الواجهات المات .

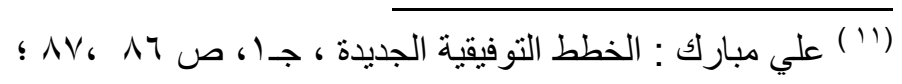

Nihal. Tamraz, Nineteenth - Century Carien Houses and Palaces, The American University in Cairo Press, 1994, pp. 26-9,38-9, pl ,2.27,2.28,2.29,2.30,2.31.

(r) ('أسماء سيد فرغلي حسنين : قصور مدينة أسيوط ، ص ؟؟. 
و ون أمثلة منشآت هذا الطر ازبمدينة القاهرة بعض المنـازل في شوارع : الموسكي

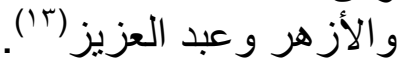

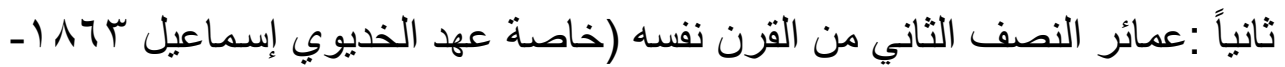

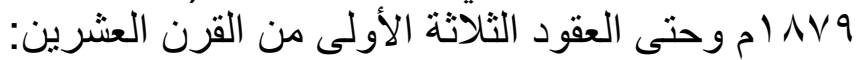

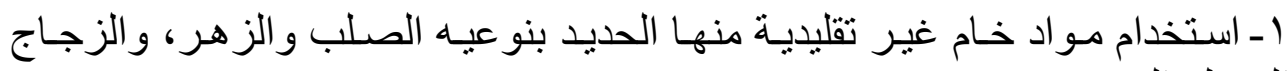

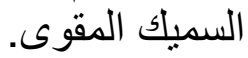

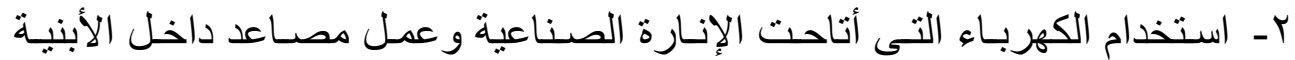
متعددة الطو ابق .

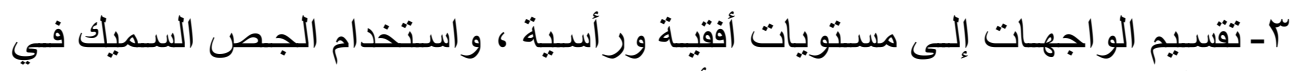

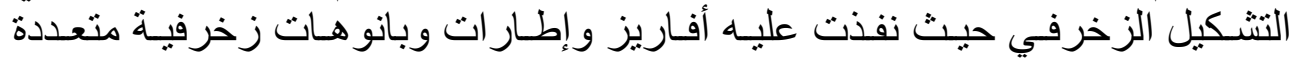
الأشكال .

$$
\text { عـ ـ بناء الطد الطو ابق حتى وصلت إلى ستة طو ابق في أحد المباني . }
$$

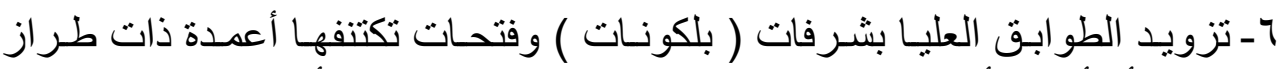

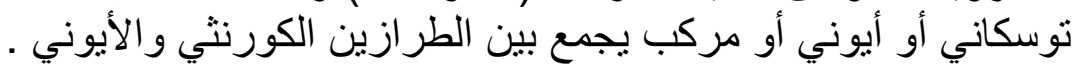

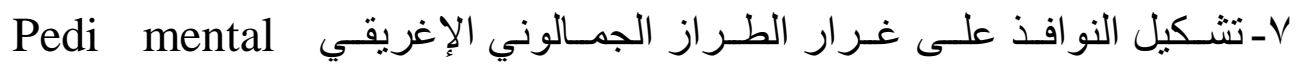

Windows

$$
\begin{aligned}
& \text { A- استخدام طر از الباروك في تشكيل الواجهات . } \\
& 9 \text { ـ العناية بتنظيم المساحات وفقاً لتصميم المبنى . }
\end{aligned}
$$

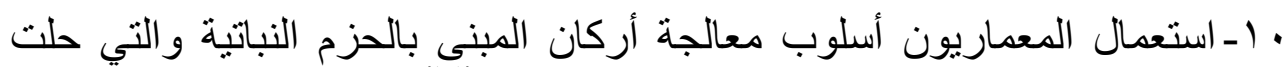

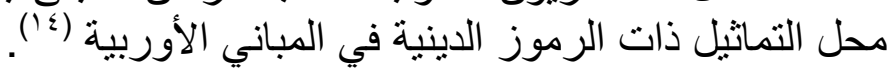

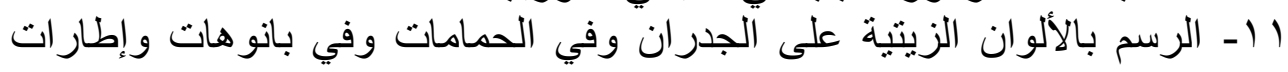
خشبية . خ

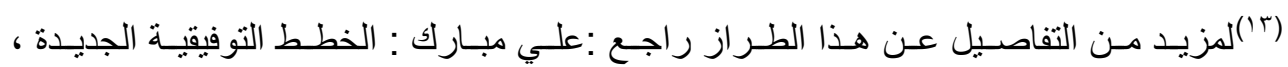
ج

Nihal. Tamraz, Nineteenth - Century Carien Houses and Palaces, pp. 26-9 ,38-9, pl ,27, $28,29,30,31$.

14) Jacob Burckhardt, The Civilization of the Renaissance, Oxford University Press, 1945, p--p.104 - 169, p.353,255,358,359,382,383; Nihal Tamraz, Nineteenth - Century Carien Houses and Palaces,pp.36-39; Cynthia Myntti , Paris Along the Nile- Architecture in Cairo from the Belle Époque, The American University in Cairo Press, 1999, p.13-15, 92-105. 
r ا - استعمال أثاث خثبي مستورد ، و أشغال زجاجية أوروبية صناعة بو هيميا .

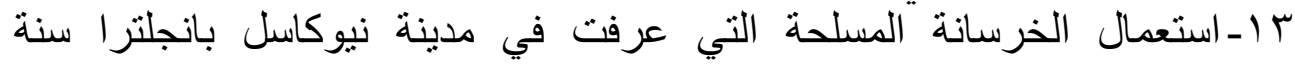
.م) $\wedge \wedge 0$ وبصفة عامة فإن أهم مظاهر هذه الطرز المعمارية المعمارية و الزخرفية هي إعادة

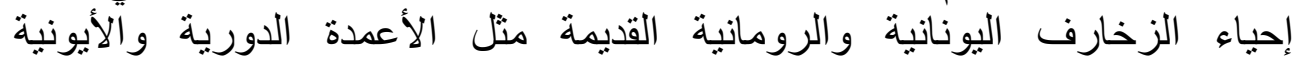

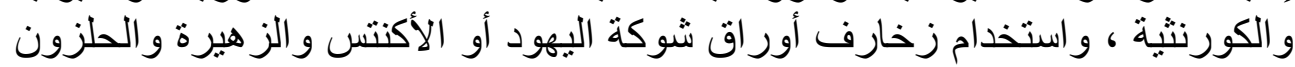

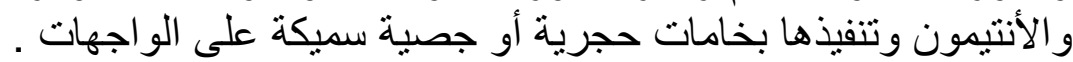

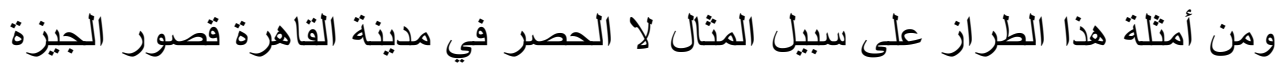

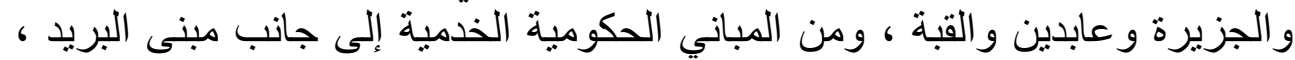

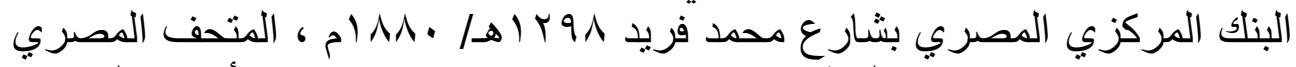

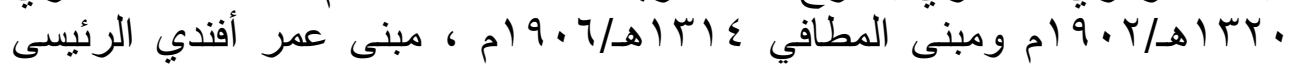

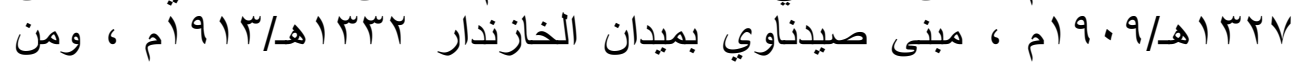

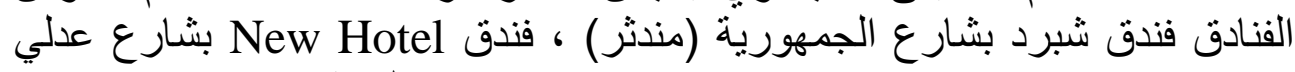

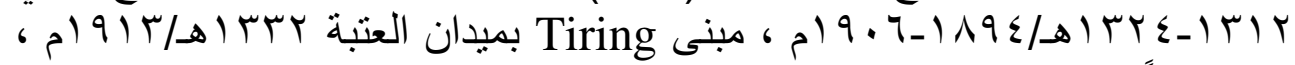

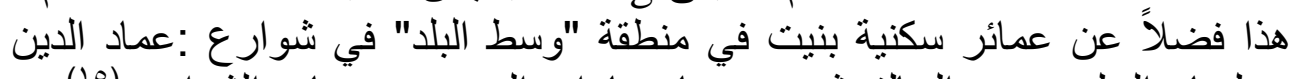

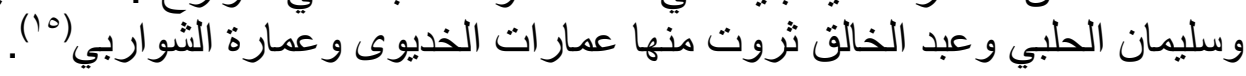

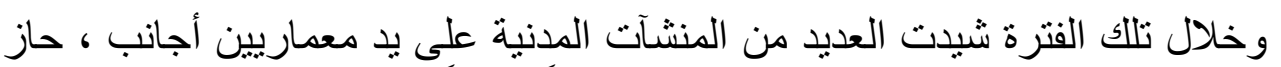

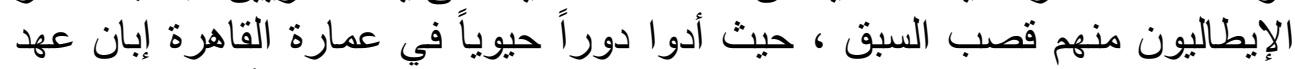

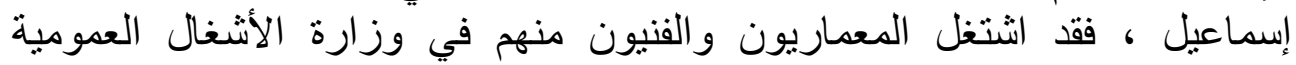

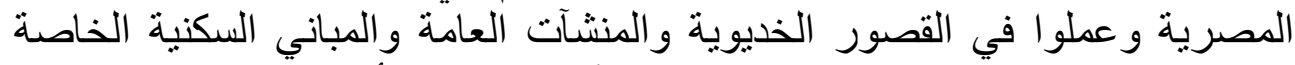

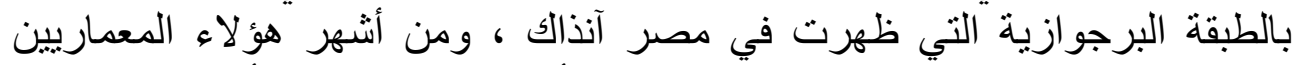
فر انشيسكو باتيجيللي، كارلو بر امبوليني، بيترو أفوسكاني (مصدم الأوبر الخئي الخديوية)،

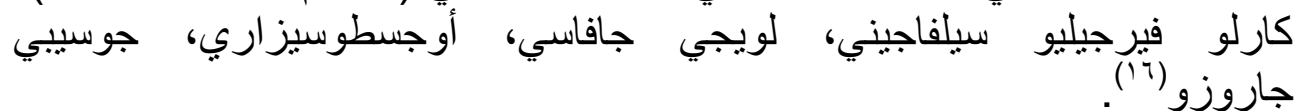

(15) Mahmoud EL-Gowhary, EX-Royal Palaces in Egypt from Mohamed Aly to Farouk, dar al-maaref,1954,p.7,40 ; Nihal Tamraz, Nineteenth - Century Carien Houses and Palaces,p.29,30,31,pl ,2.44,2.47,2.48,2.51 ; Cynthia Myntti , Paris Along the Nile, p. $15,26,32,85$.

('ا') أمجدي علوان وآخرون: عمارة وفنون أسرة محمد علي دراسات وبحوث ،دار الحكمة، القاهرة،

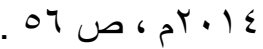


إلى جانب ذللك وجد معماريون فرنسيين أمثال راؤول براندون مصمم مبنى

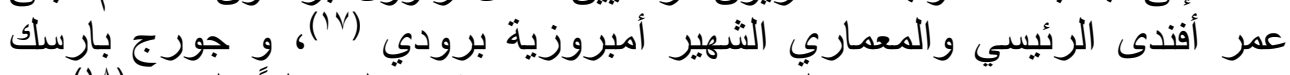

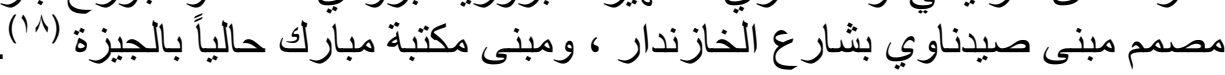

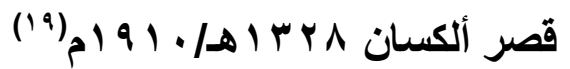
الموقع: يطل القصر على النيل مباشرة ، ويبعد حوالي . . . م م عن قناطر أسيوط

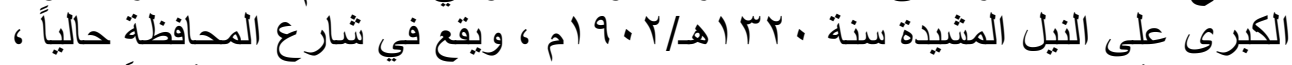

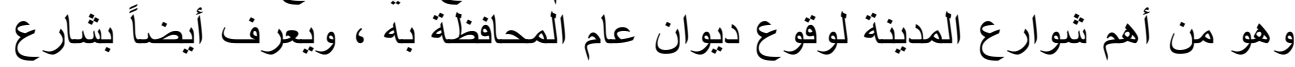

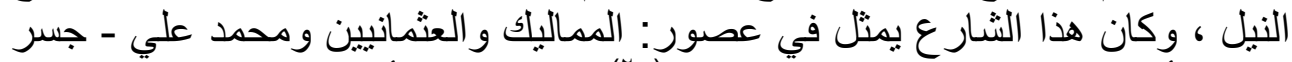

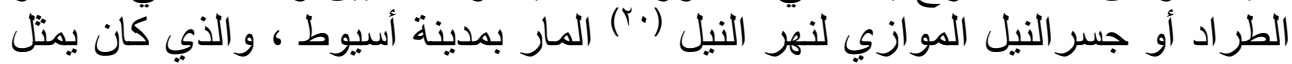

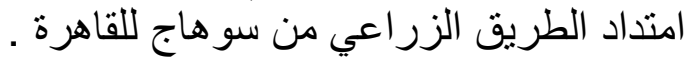

(17)) Volait ,Mercedes , Ambroise Baudry , L 'Egypt d 'un Architecte, Paris :Gallimard ,1998.

(18)) Cynthia Myntti, Paris Along the Nile, p. 14.

(9 (1) القصر مسجل كأثر بين الآثار الإسلامية بمدينة أسيوط ، حيث قامت وزارة الآثار بنز عل ملكيتة

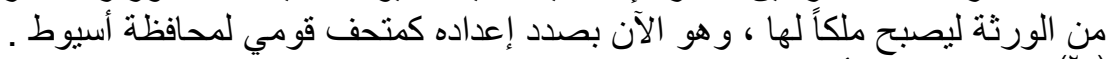

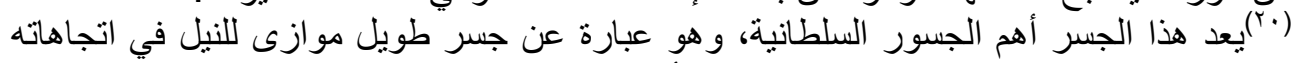

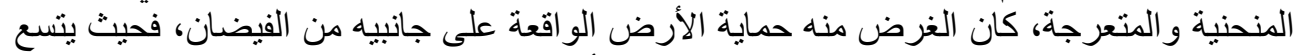
النهر تضيق المسافة بينه وبين الجسر، وتفسير ذللك أنه كلما قل اتساع المجرى كلى كلما اتجهت فئ مياه

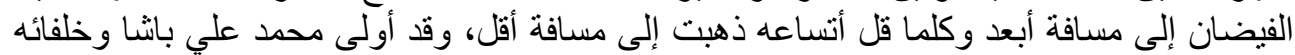
أهمية خاصة لجسر الطراد أو جسر النيل، وتراوحت مظاهر هذا الاهتمام بين التقوية واستكمال

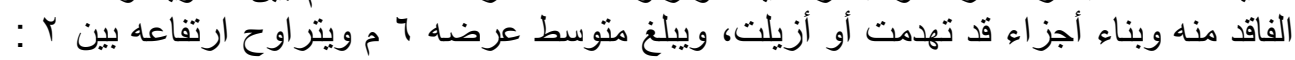

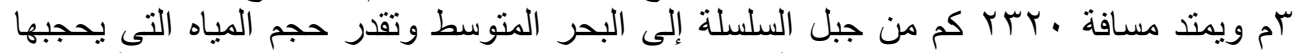

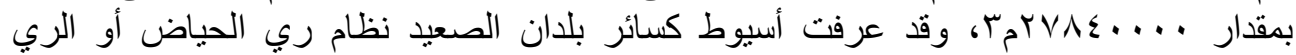

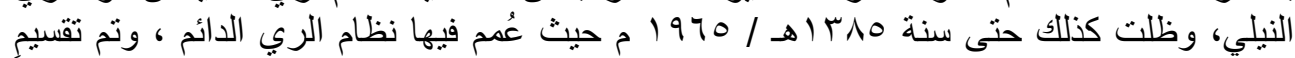

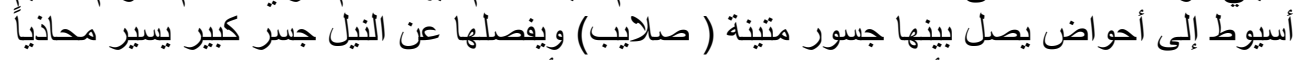

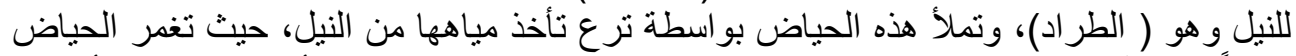

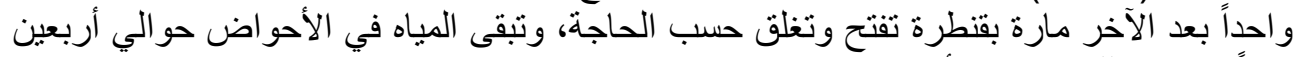

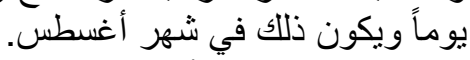
ولا زالت كثير من آثار هذا الجسر موجودة في أسيوط في صورة حورة ائط أو أسوار مرتفعة من الطوب ترتفع عن مستوى السهل الفيضي، وقد أستغل جسم طراد أسيوط - في جزء هئ كبير منه

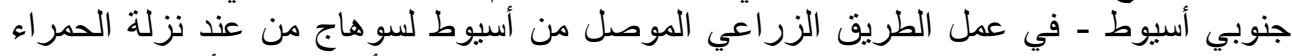

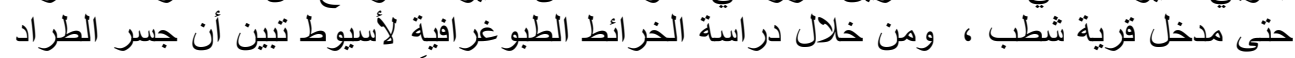

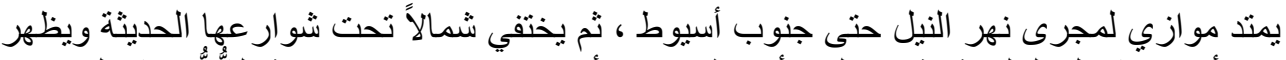

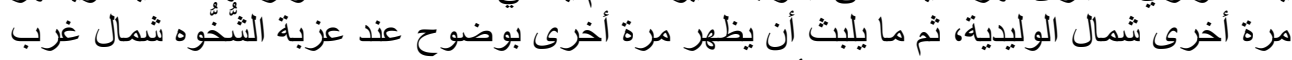

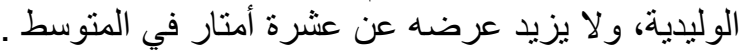




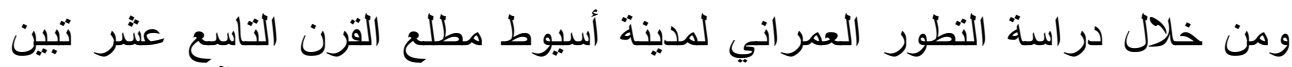

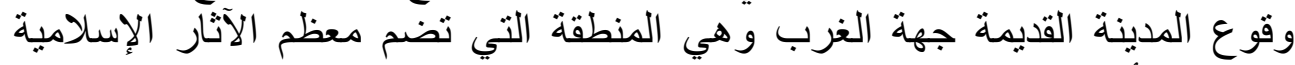

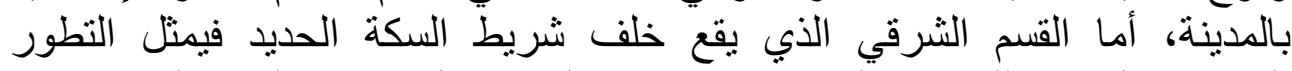

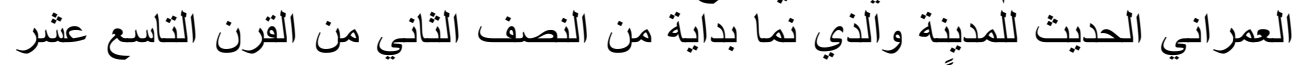

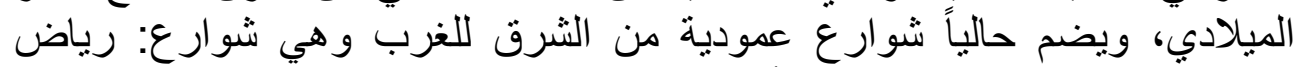

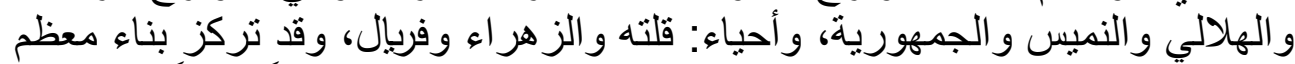

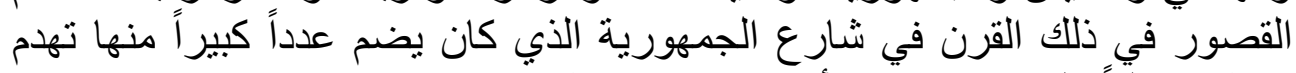

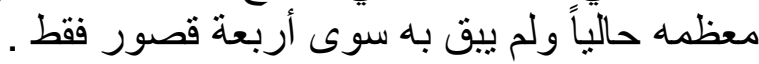

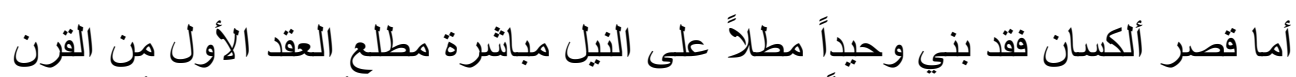

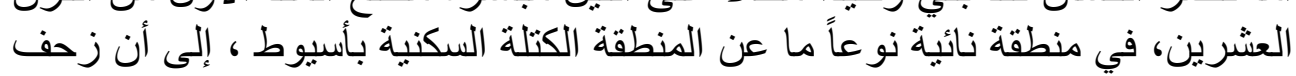

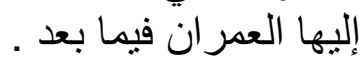

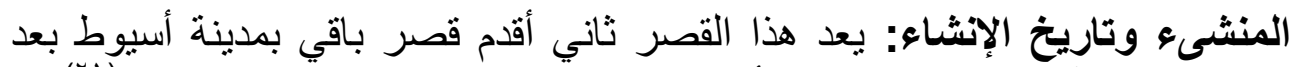

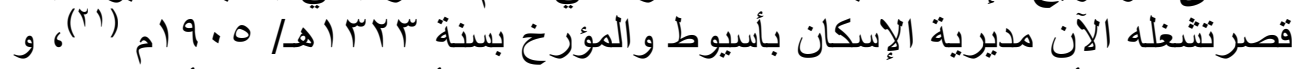

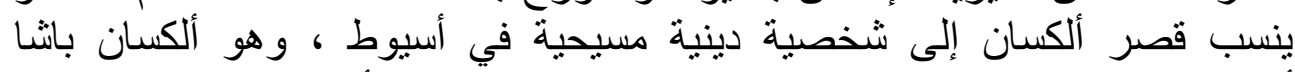
أبسخيرون ، الذي ينتمي لو احدة من العائلات المسيحية في أسيوط ، ولدية في في مركز

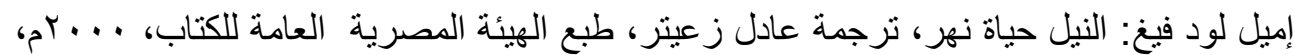

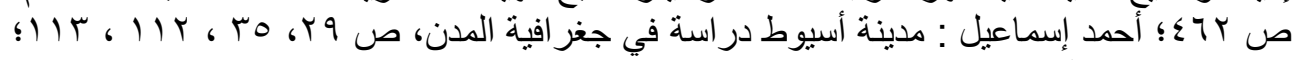

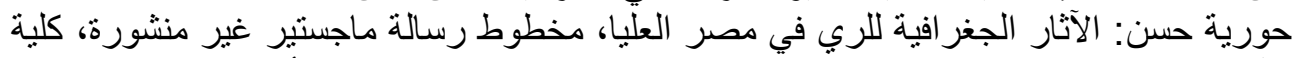

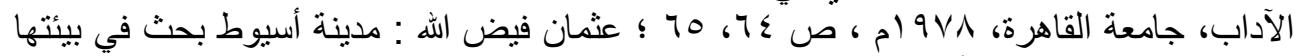

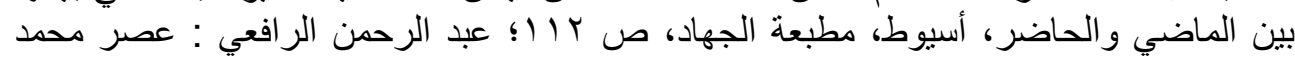

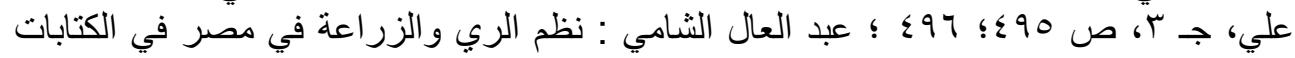

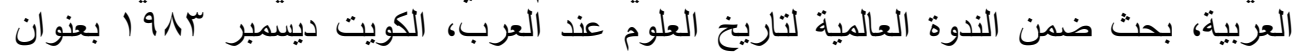

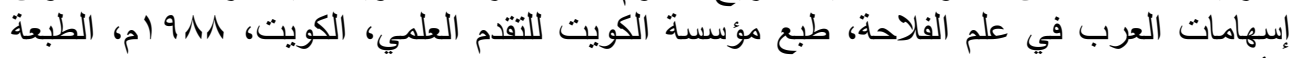

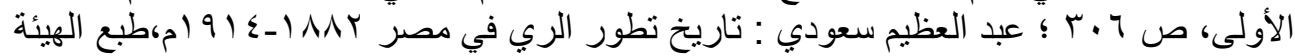

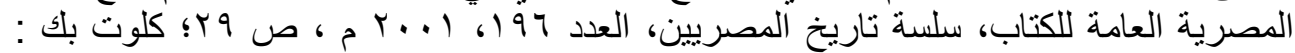

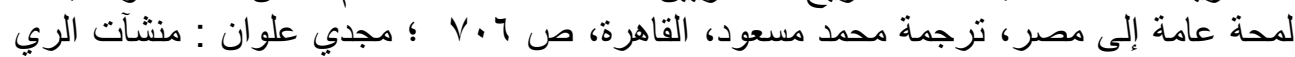

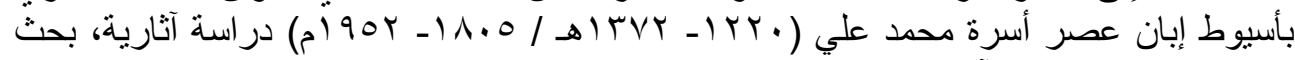

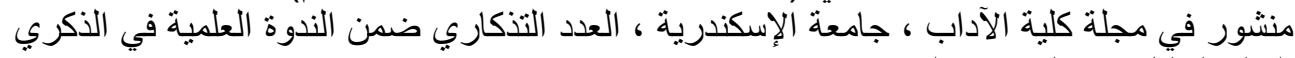

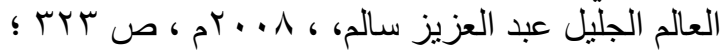

Helen Anne B.Rivlin., The Agricultural Police of Muhammad Ali in Egypt, Harvard University Press, 1961, P.238.

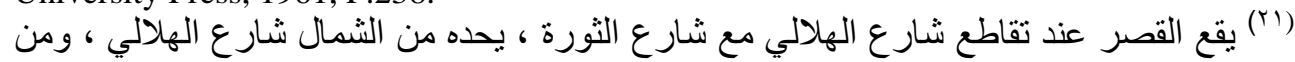

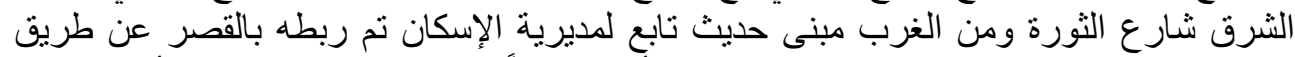

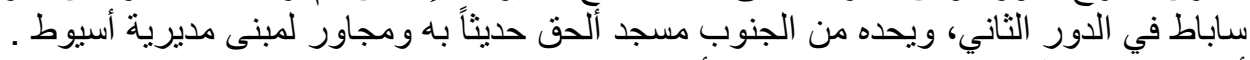

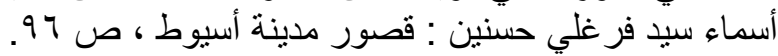




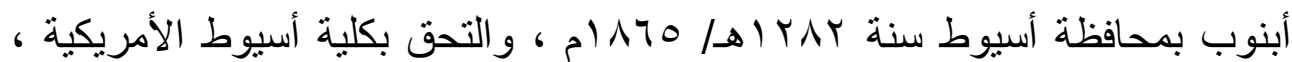

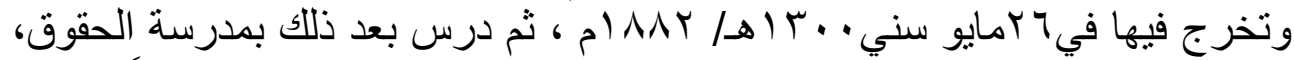

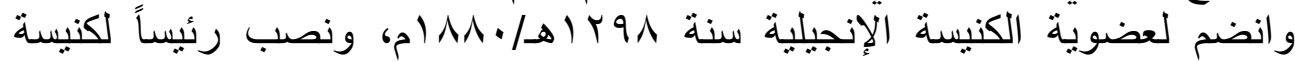

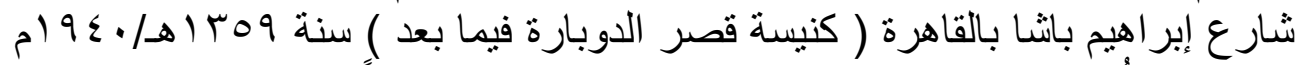

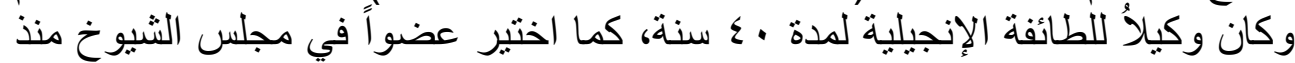

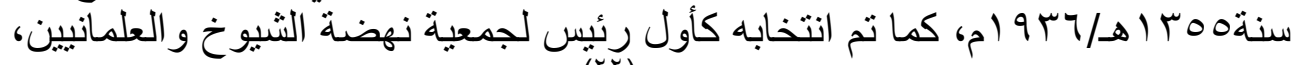

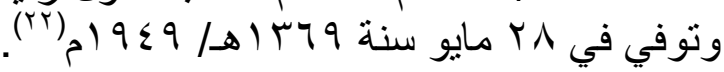

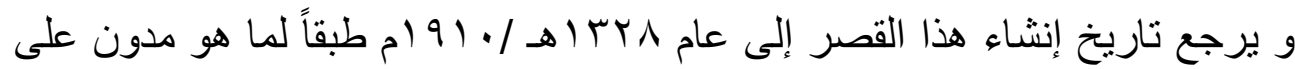

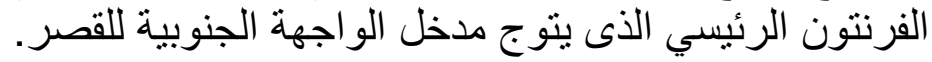

الوصف العام : للقصر أربع واجهات صممت مع القصر في وضع إنشائي هندسي

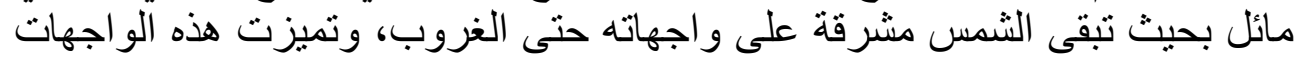

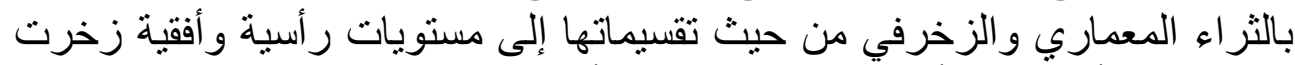

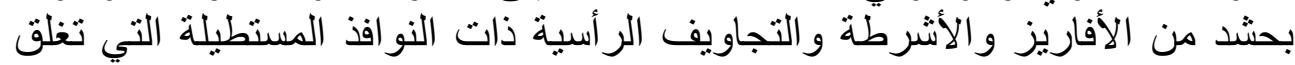

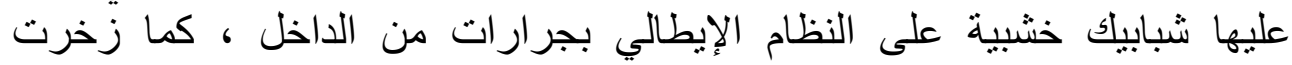

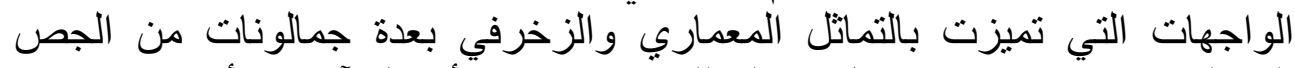

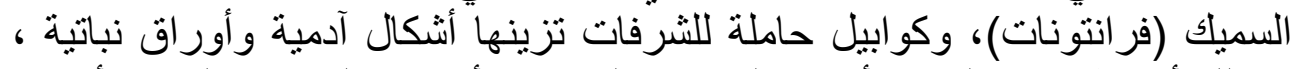

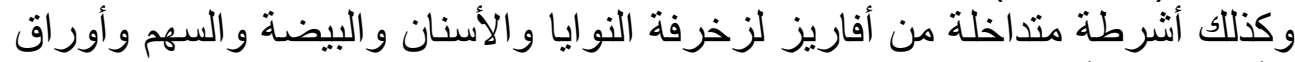

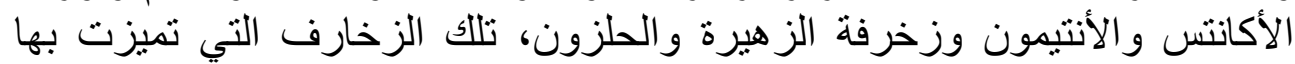
العمائر السكنية في القرن التاسع عثرو النصف النير الأول من القرن العثرين.

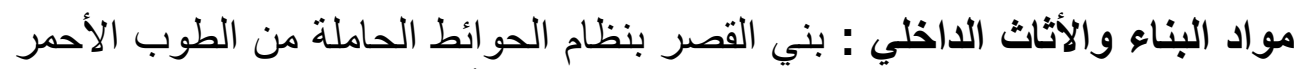

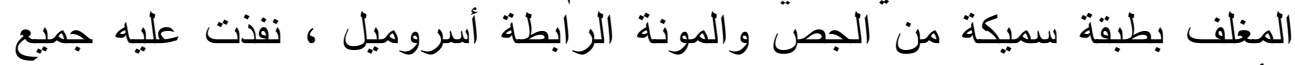

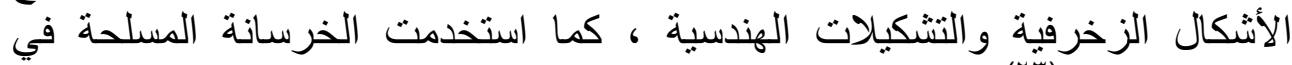

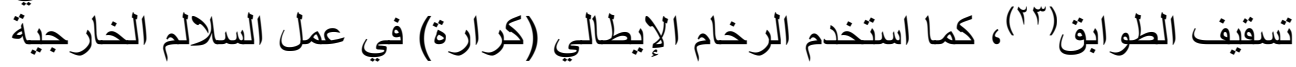

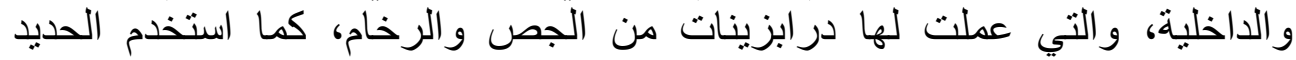

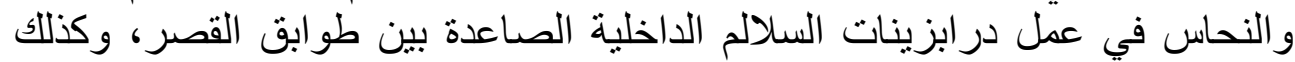

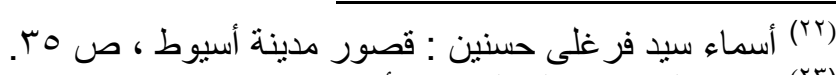

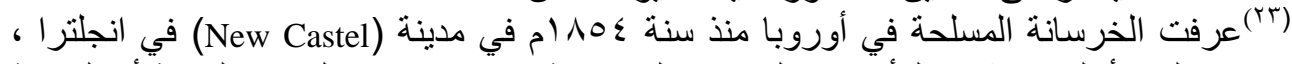

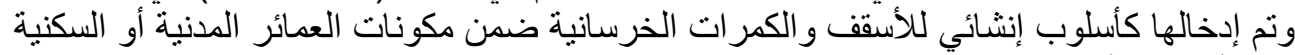

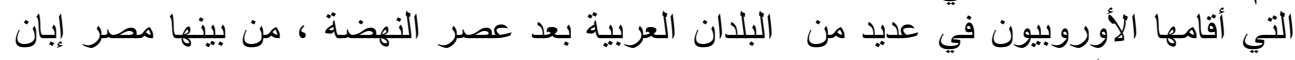

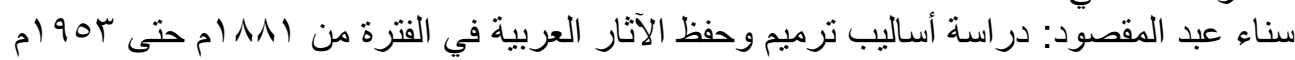

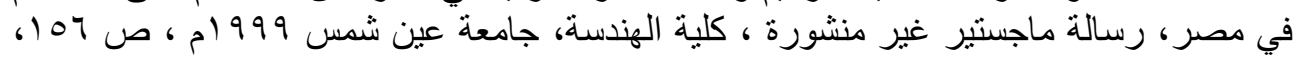


في عمل كوابيل تحمل أدوات الإنارة الصناعية من شمعدانات نحاسية ونجف

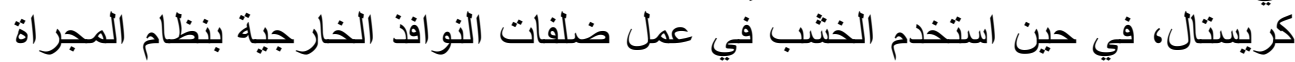

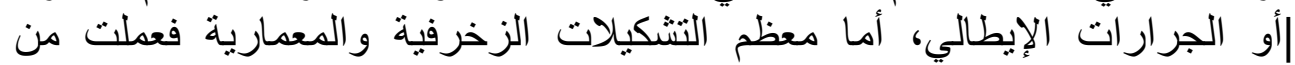
الجص السميك المنظم في أشرطة وأفاريز رأسية و أفقية.

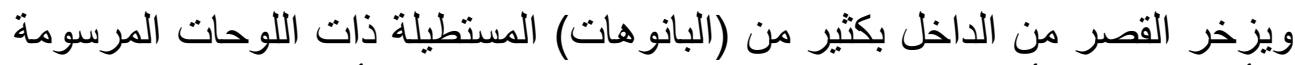

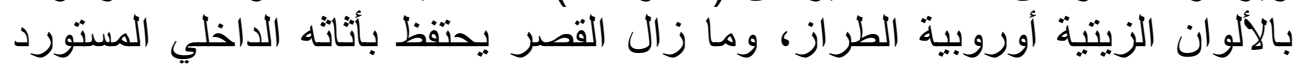

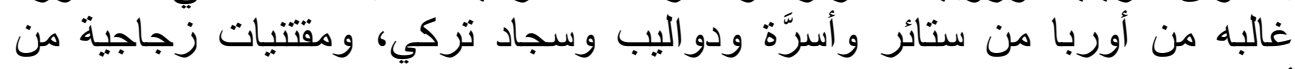

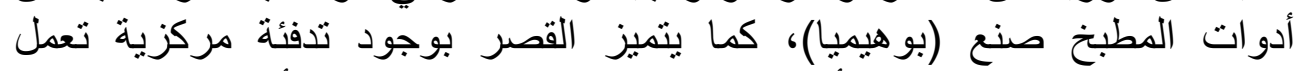

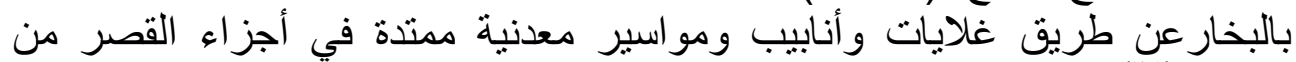
البدروم (r\&)

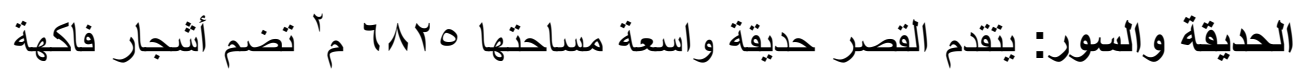

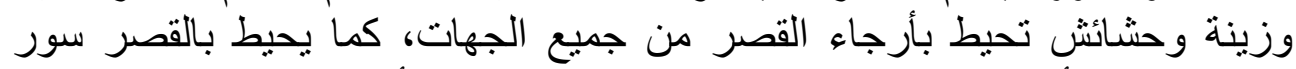

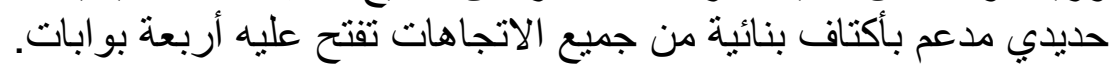

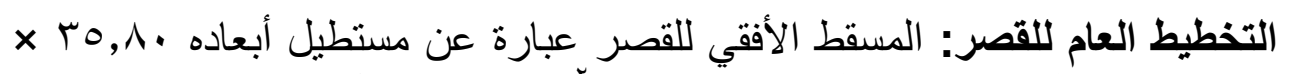

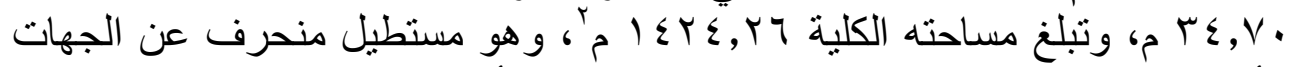

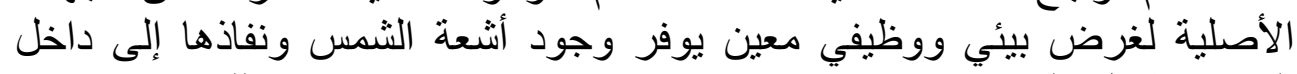

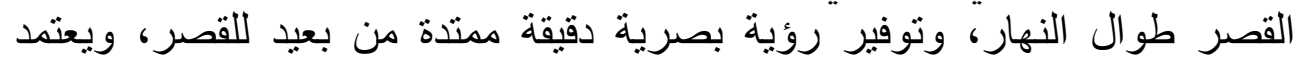

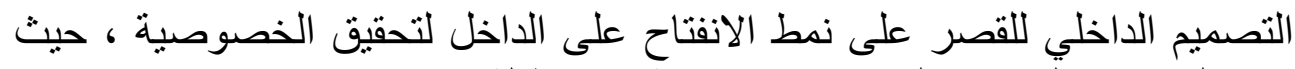
تفتح الصالات الكبرى على حجر ات مربعة ومسنطيلة.

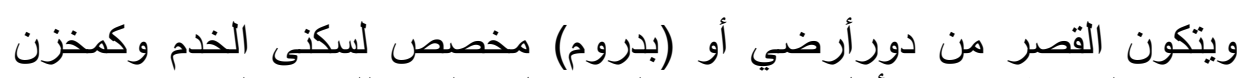

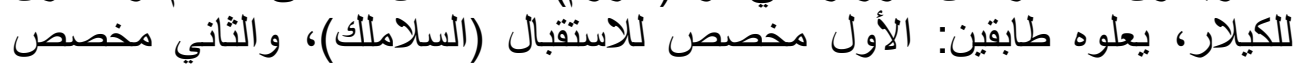

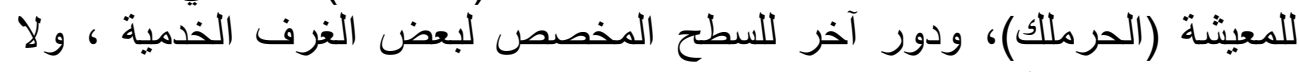

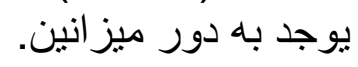

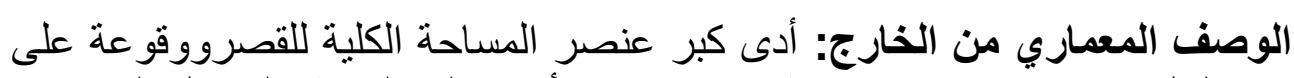

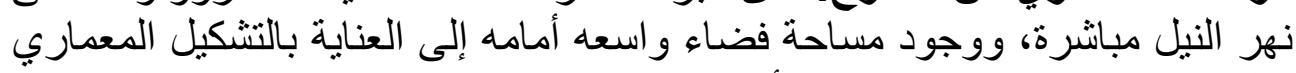

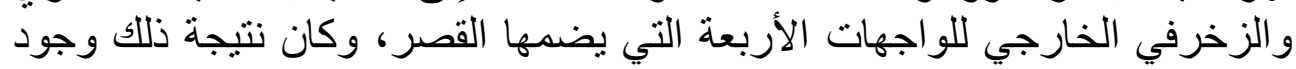

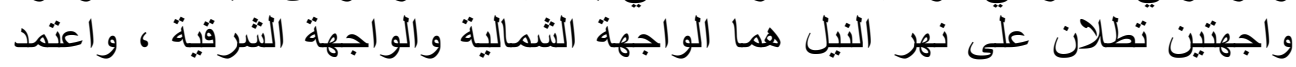

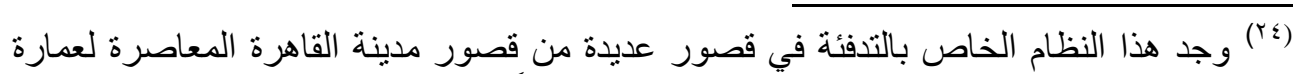

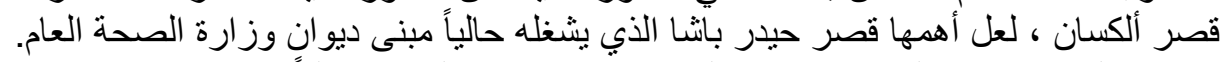

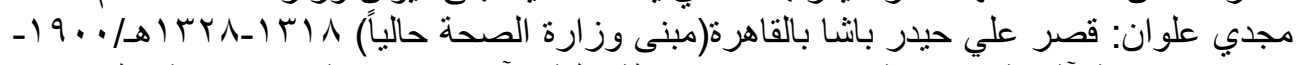

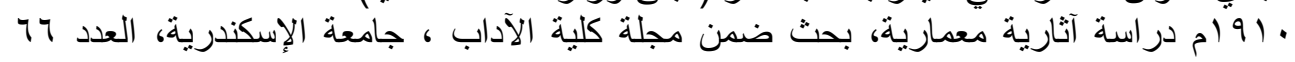

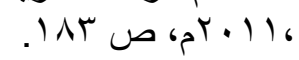




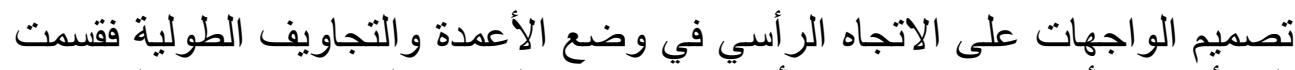

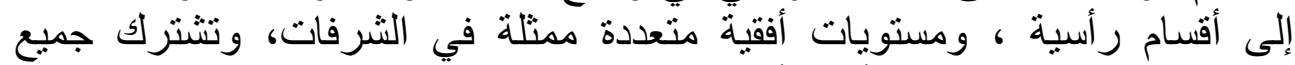

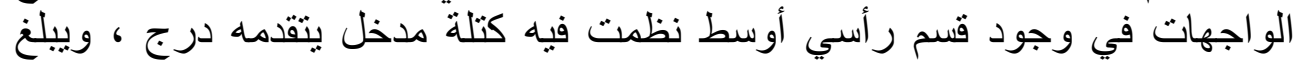

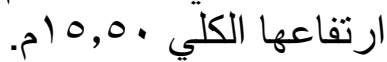

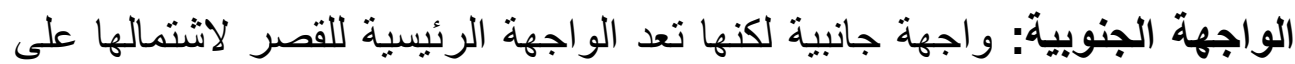

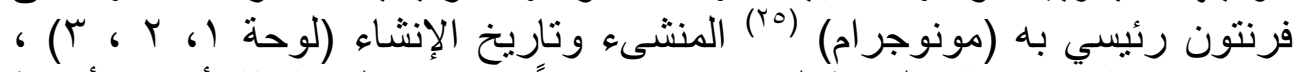

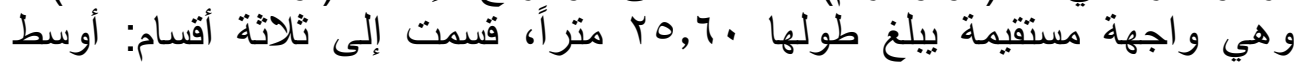

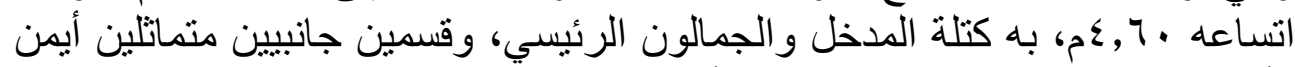

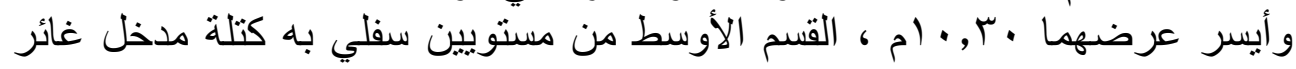

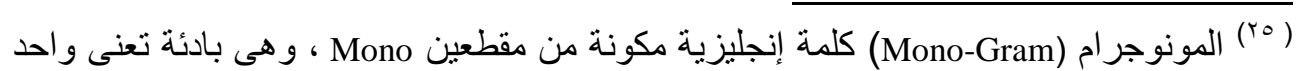

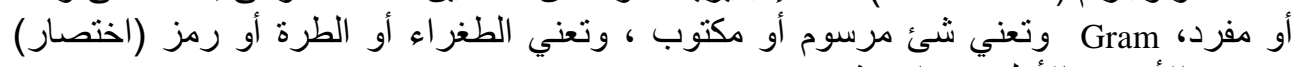

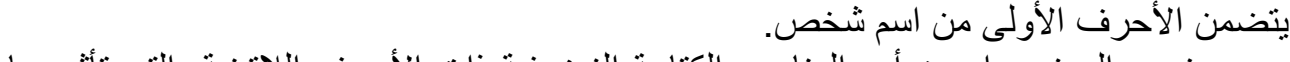

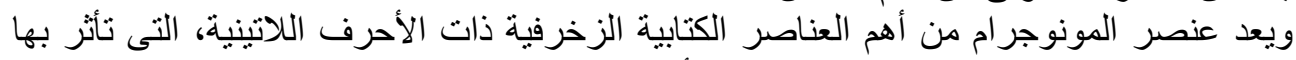

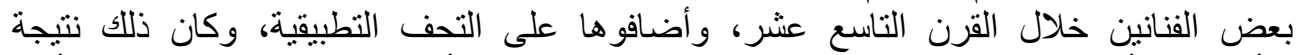

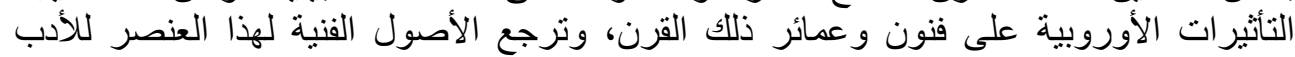

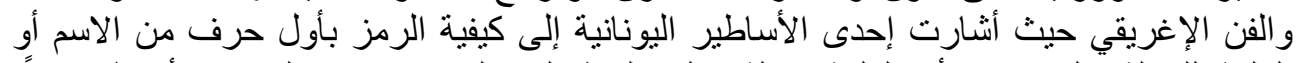

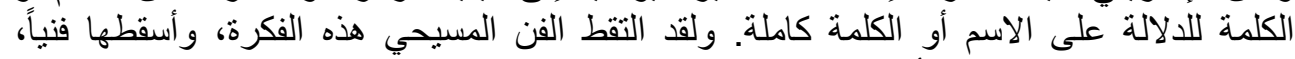

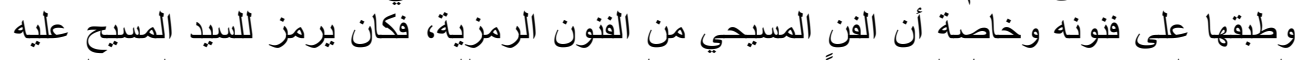

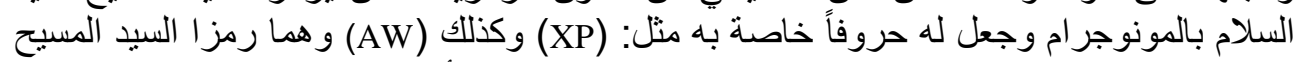

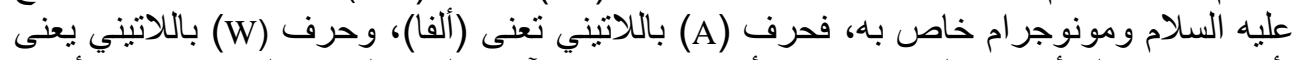

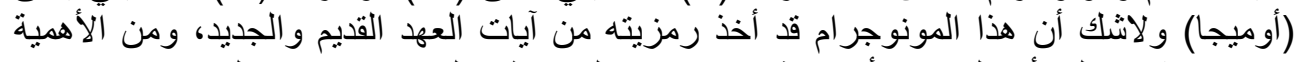

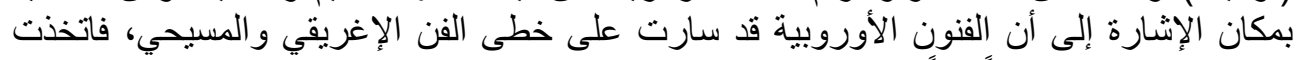

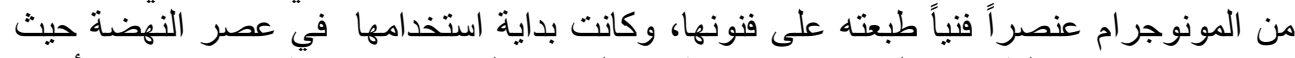

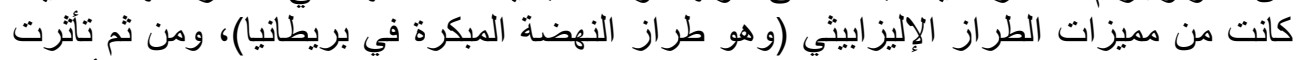

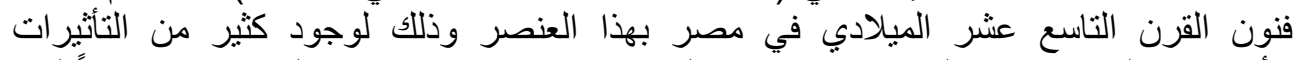

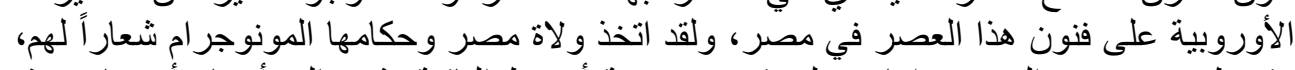

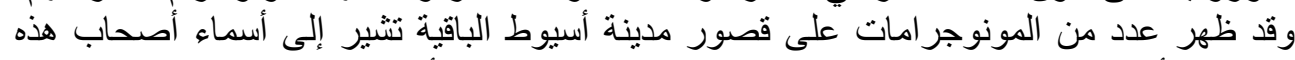

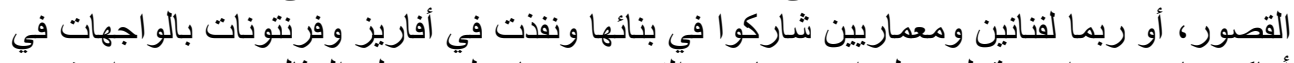

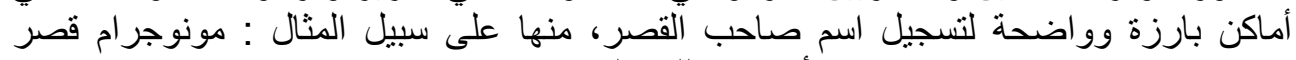

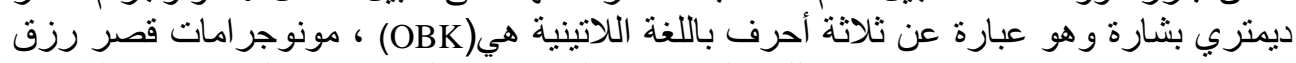

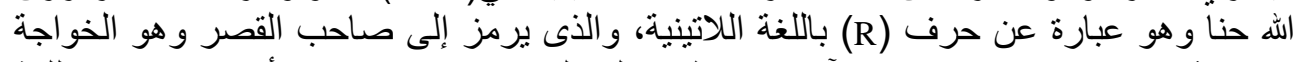

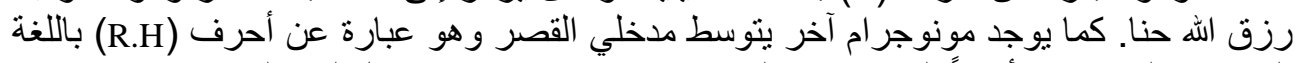

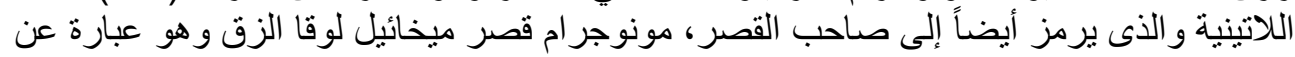

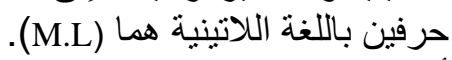

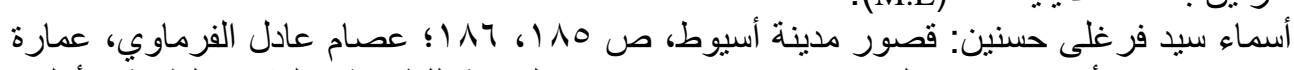

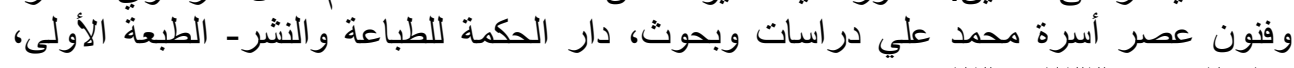
( 10 
اتساعه זم، تتقدمه بسطة مستطيلة ودرج رخامي من ست درجات، يكتنفها عمودان

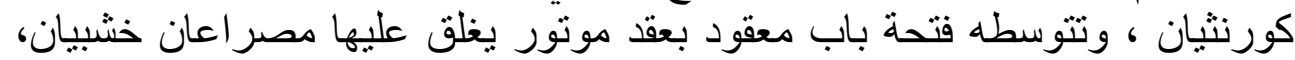

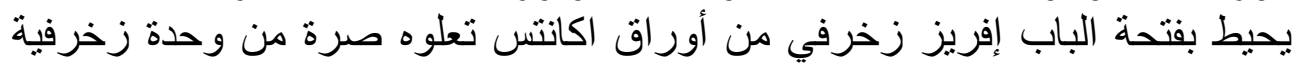

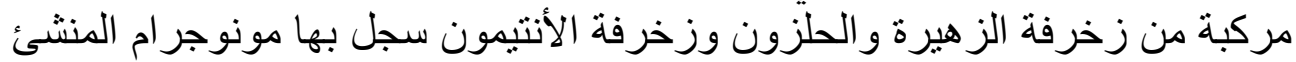

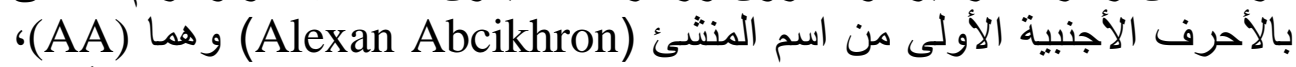

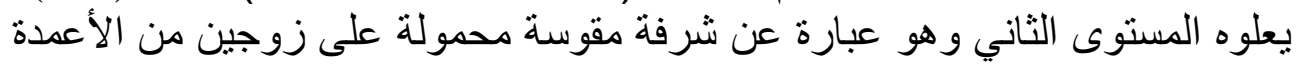

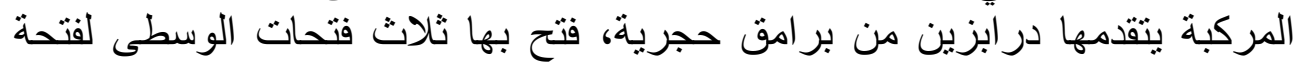

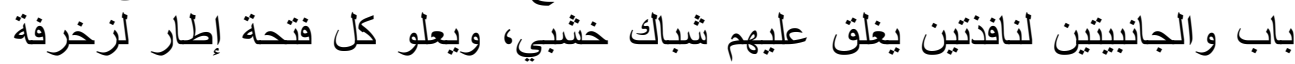

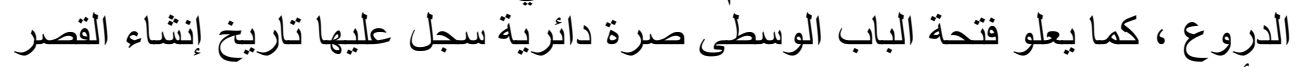

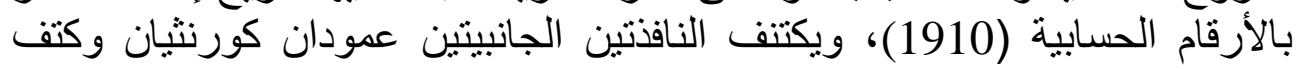

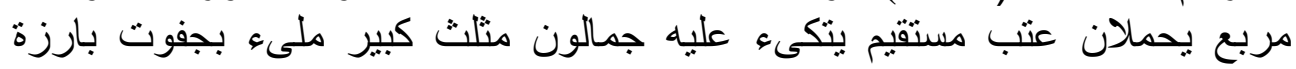

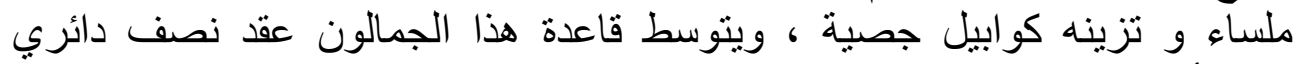

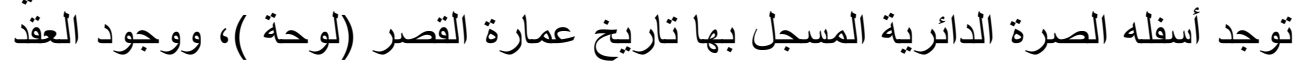

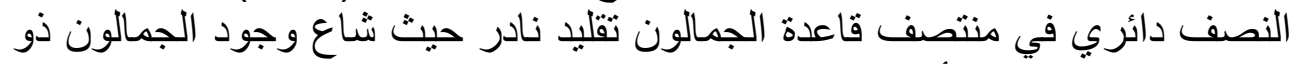
القاعدة المستقيمة دون أيه فتحات .

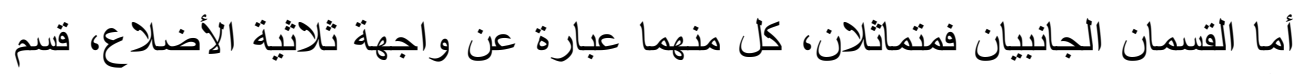

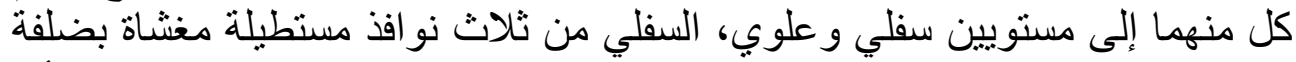

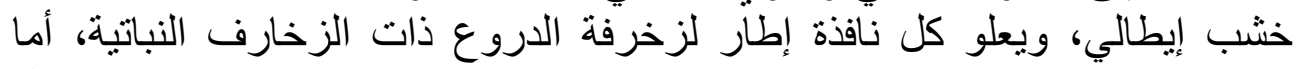

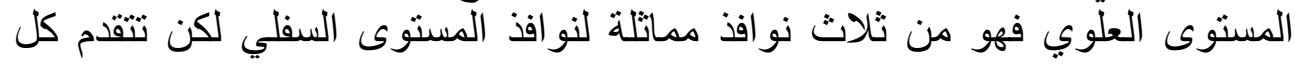

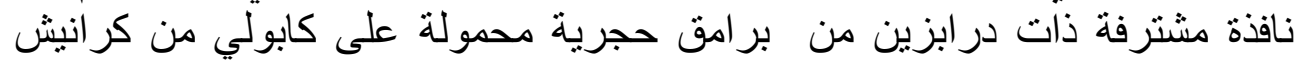

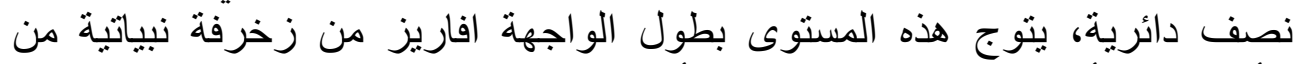

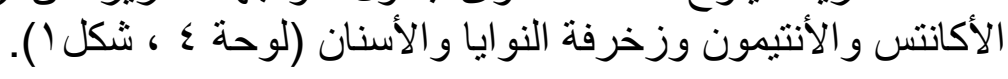

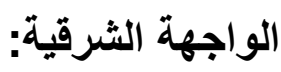

يتوفر في هذه الواجهة خصوصية صاحب القصر فهي تطل على حديقة القصر

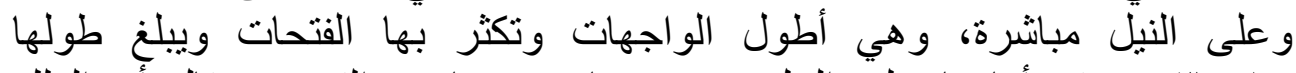

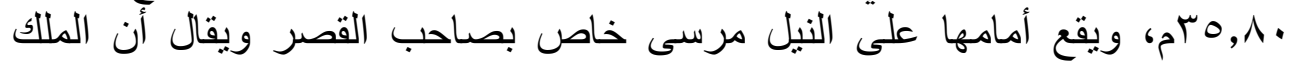

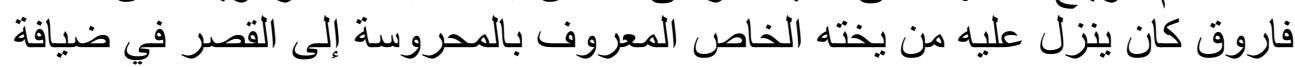

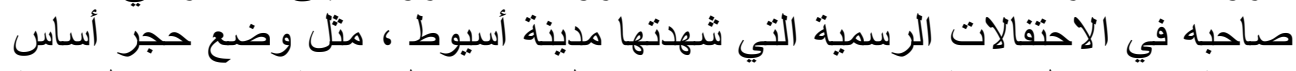

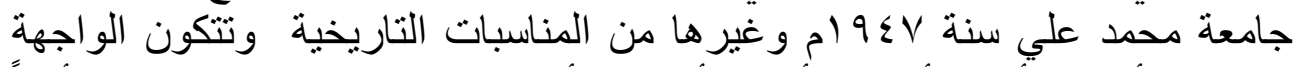

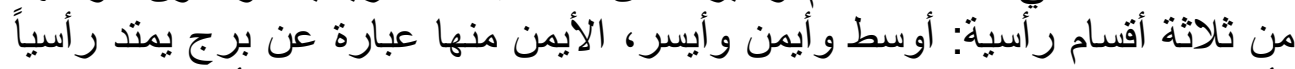

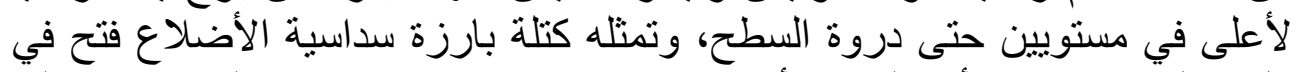

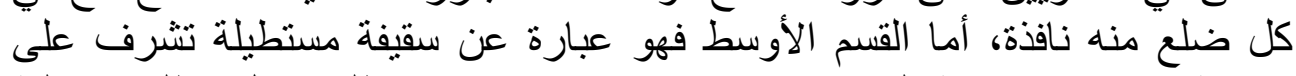
مساحة فضاء في حديقة القصر، يتقدمها درج رخامي من مطلعين كل مطلع من قلبة 


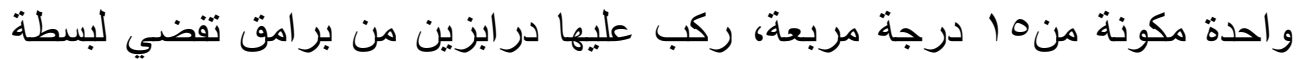

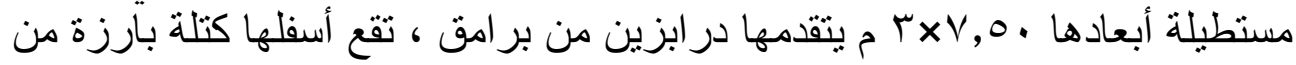

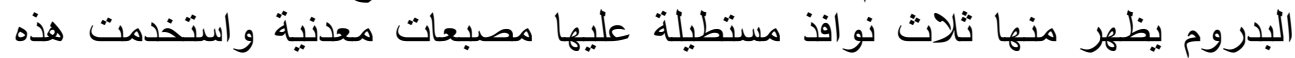

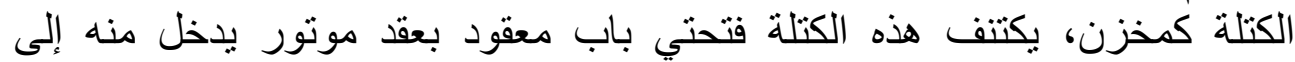

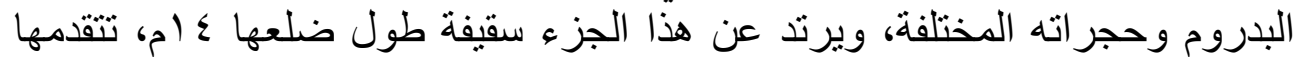

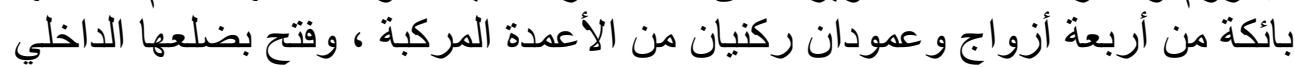

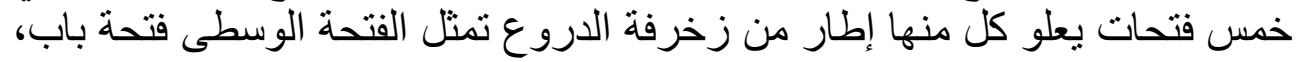

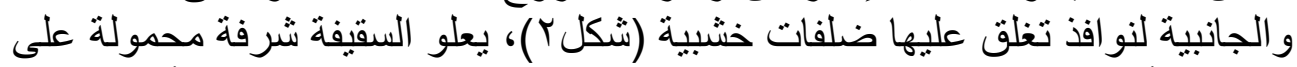

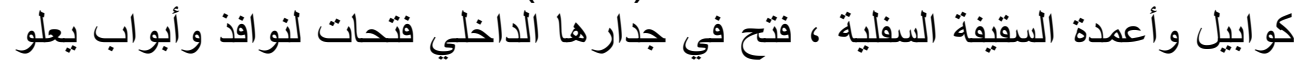

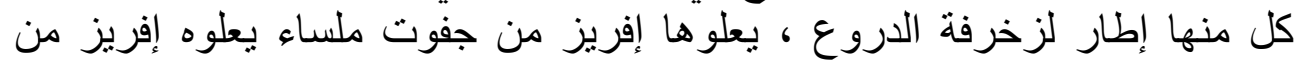

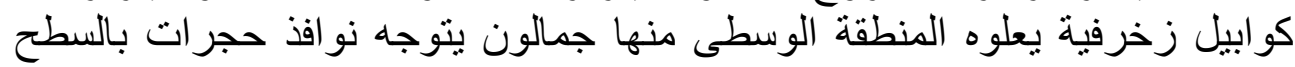

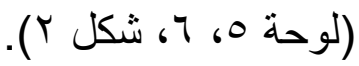

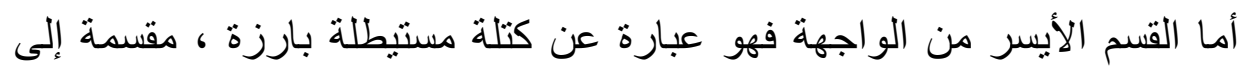

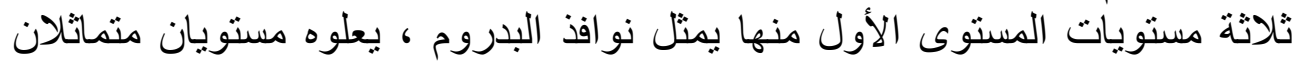

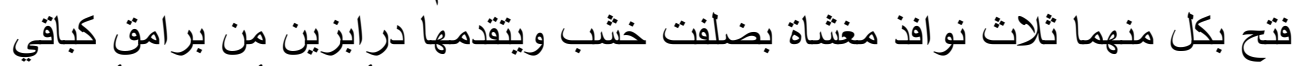

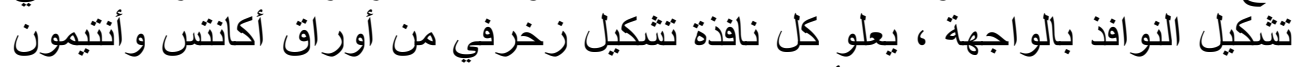

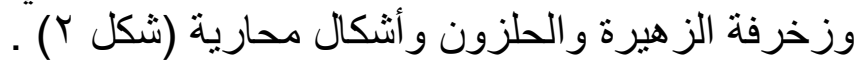

\section{الواجهة الشمالية:}

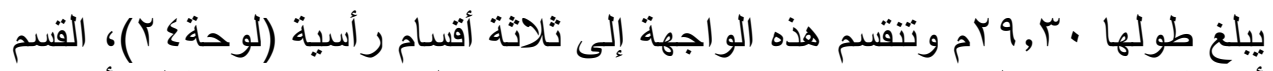

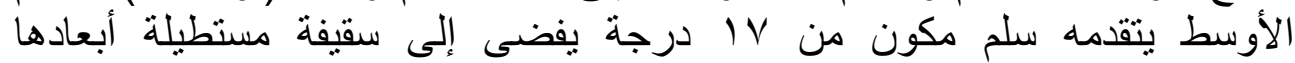

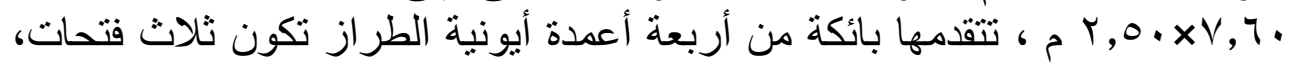

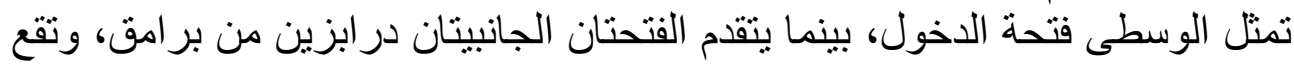

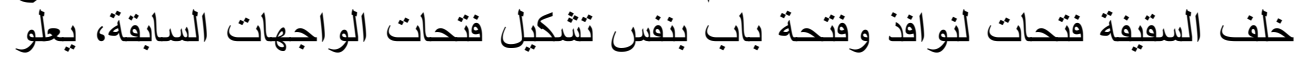

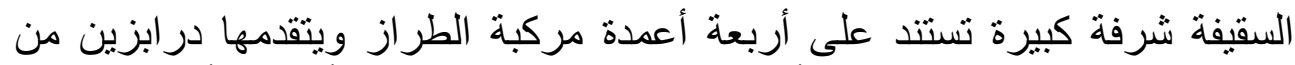

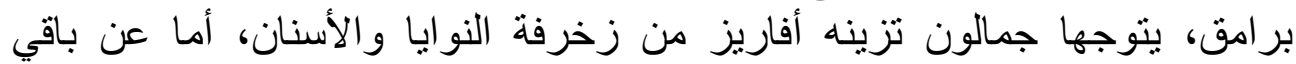

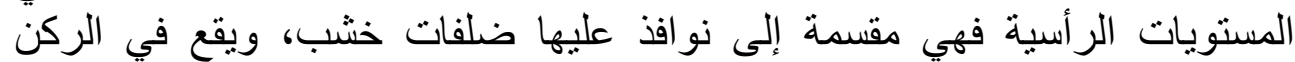

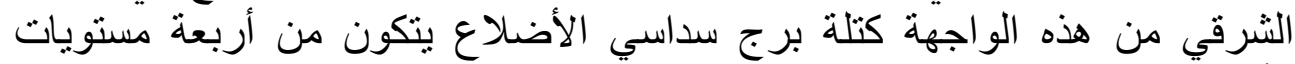

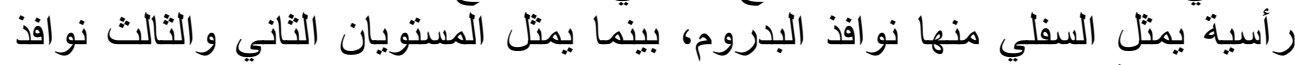

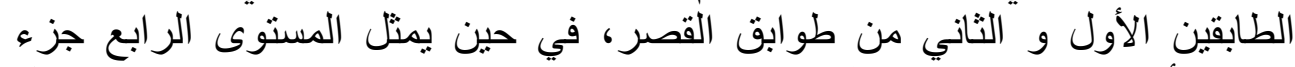

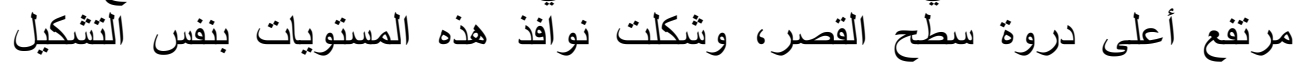
الزخرفي لنو افذ الواجهات السابقة . دروة 
الواجهة الغربية: تعتبر هذه الواجهة من أكثر واجهات القصر ازدحاماً بالوحدات

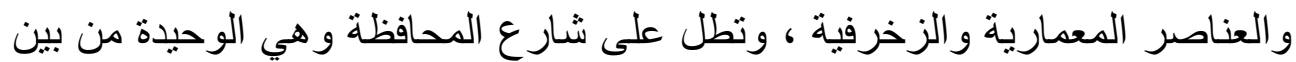

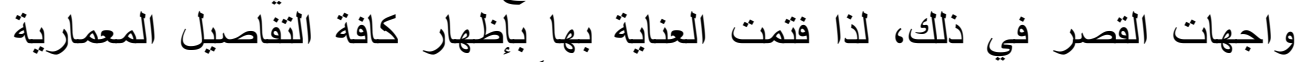

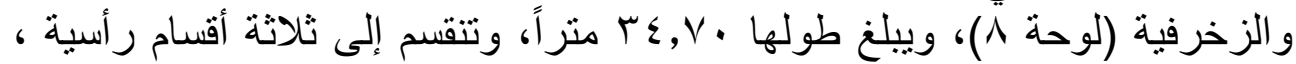

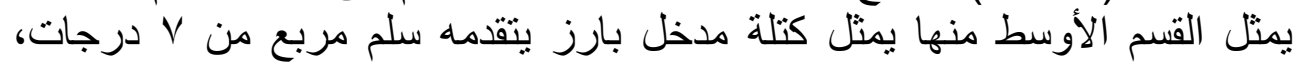

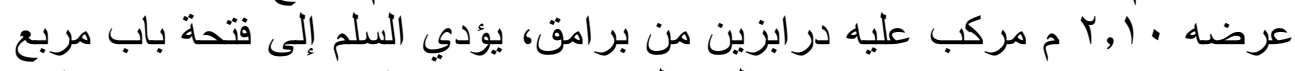

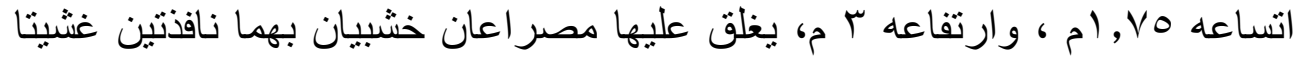

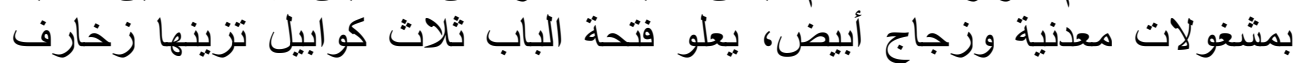

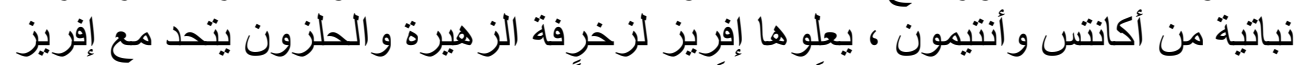

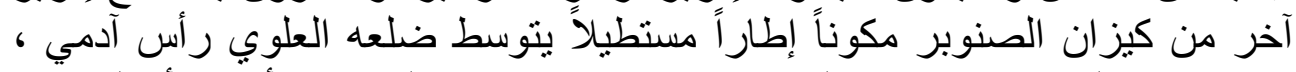

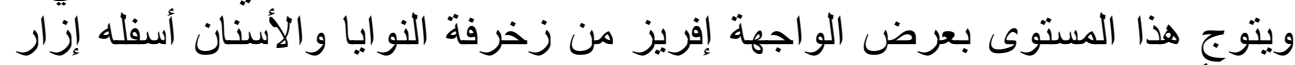

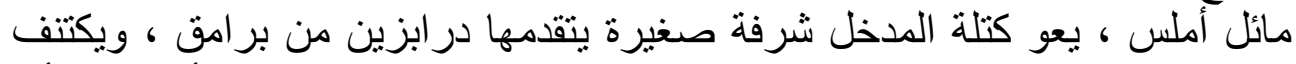

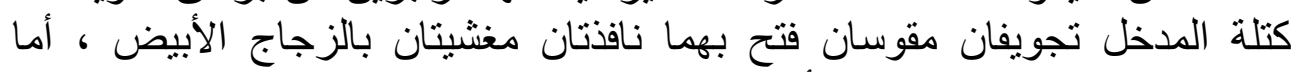

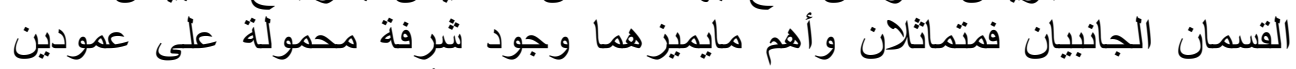

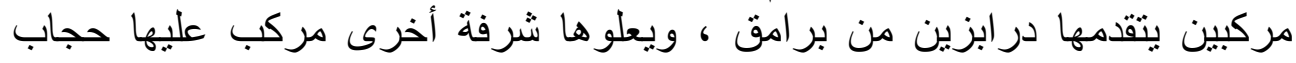

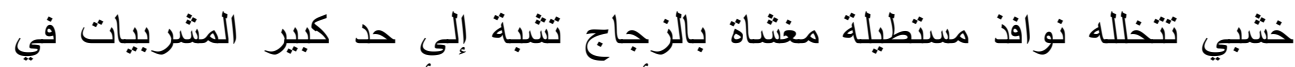

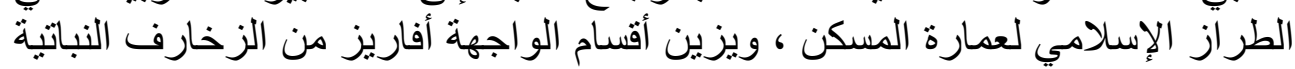

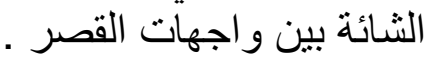

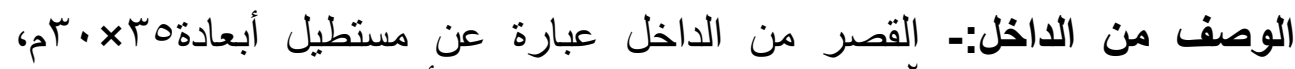

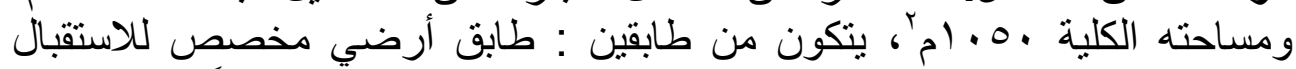

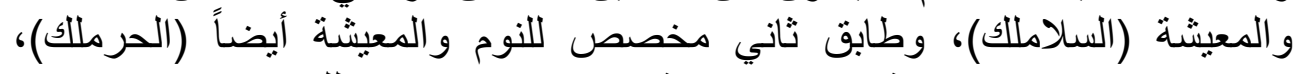

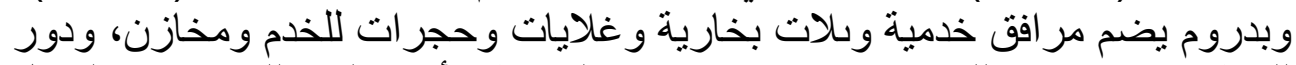

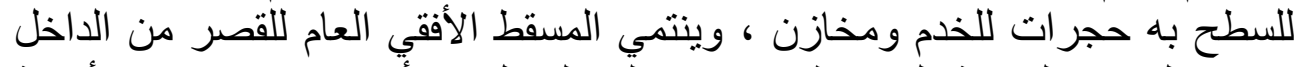

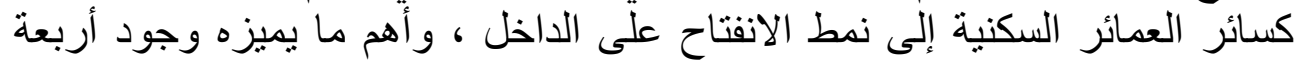

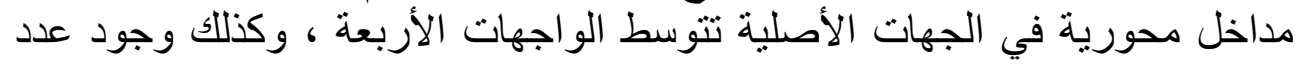

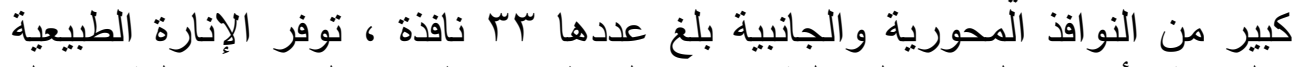

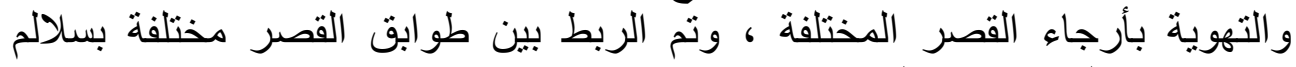
رخامية من قلبة واحدة وقلبتين (جناحين) .

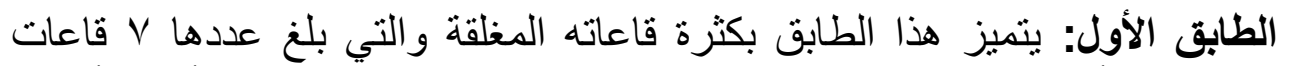

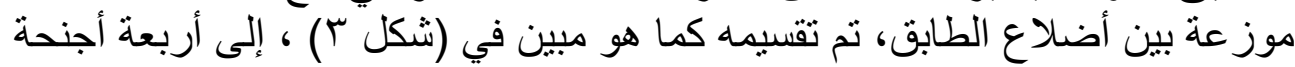

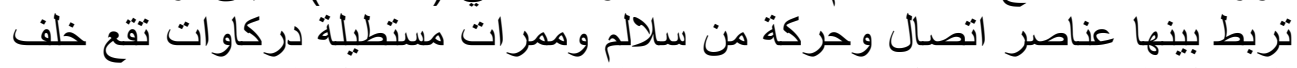

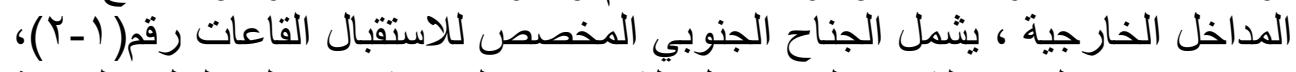

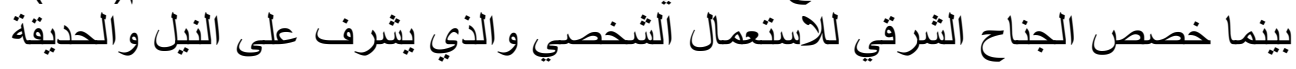


مباثرة ويشمل القاعات (Y-T)، بينما خصص الجناح الغربي للاستقبال وخصصت

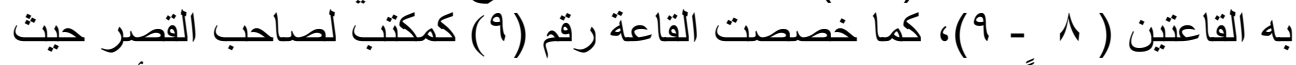

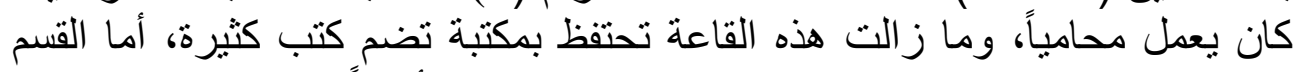

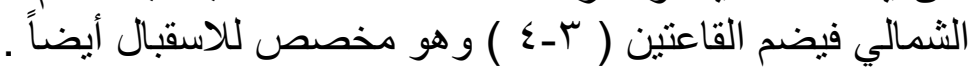

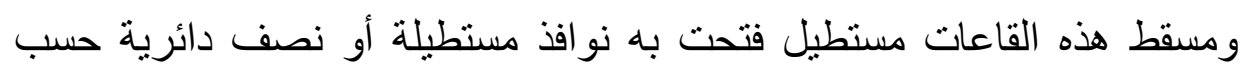

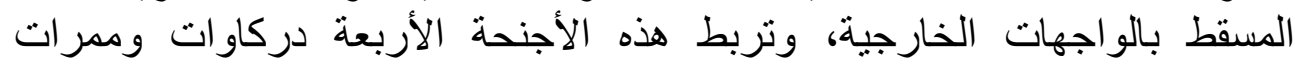

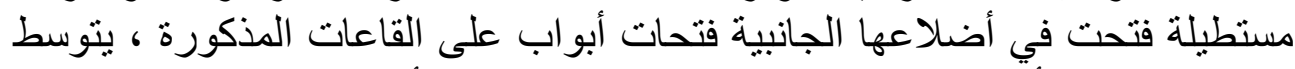

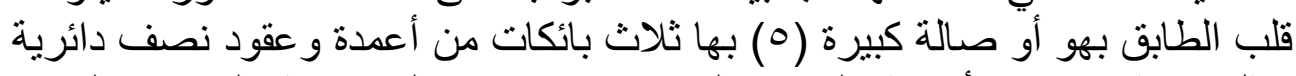

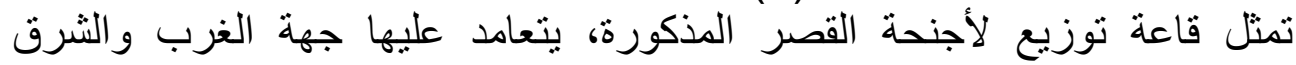

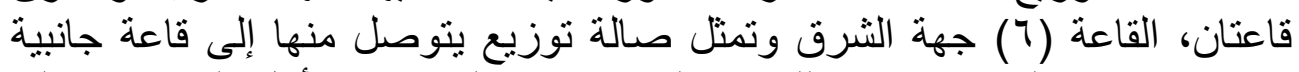

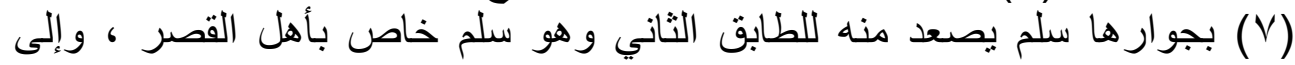

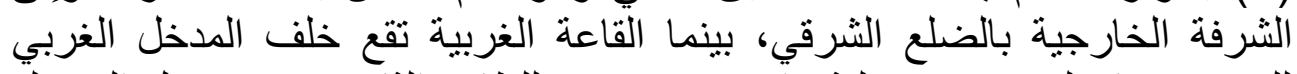

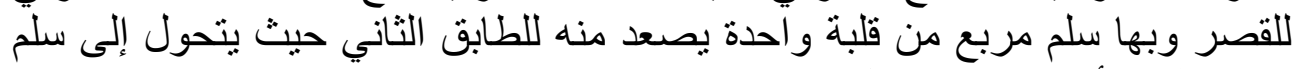
من مطلعين أو جناحين (شكل من بـ ، ع ) .

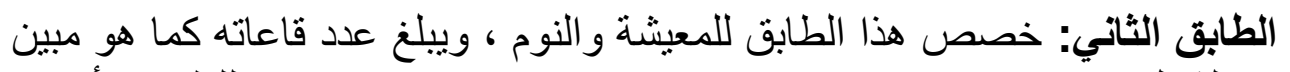

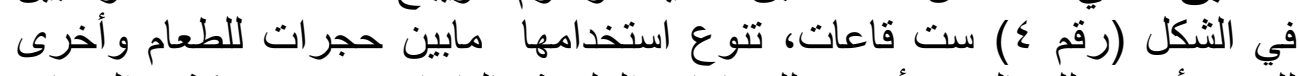

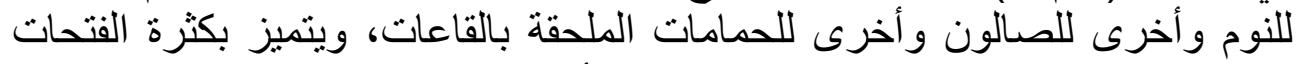

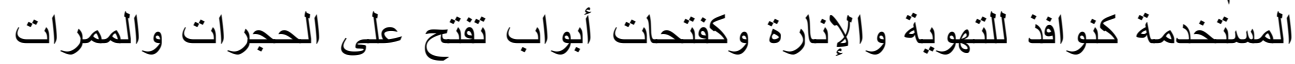

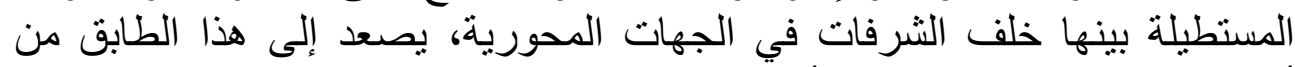

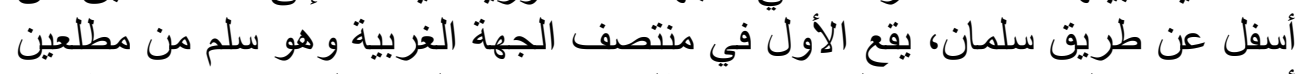

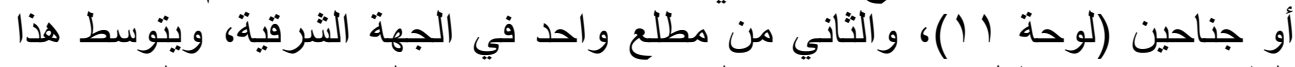

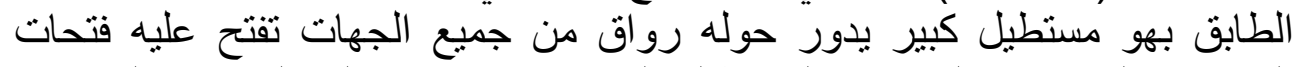

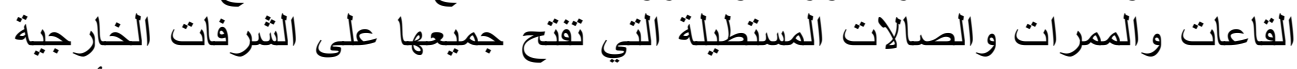

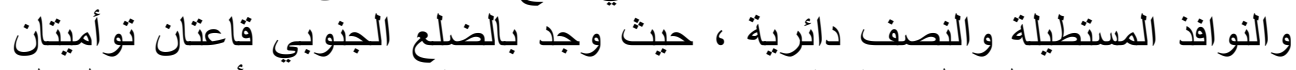

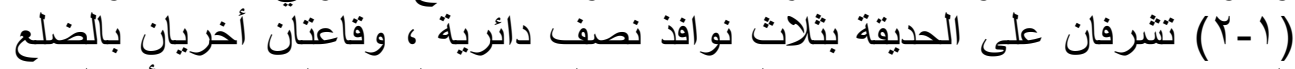

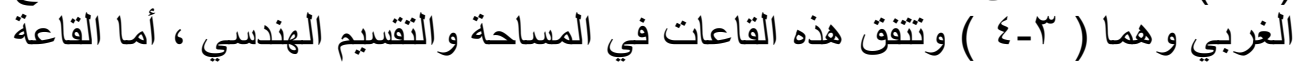

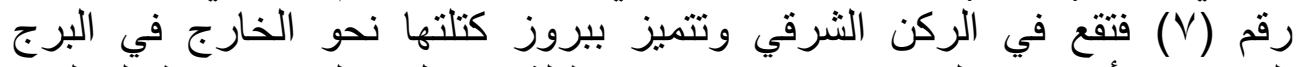

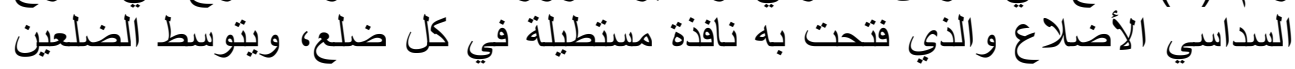

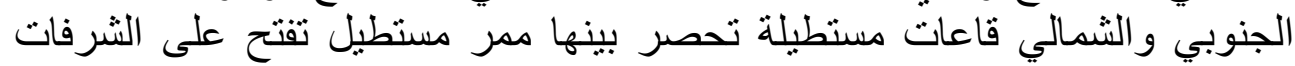

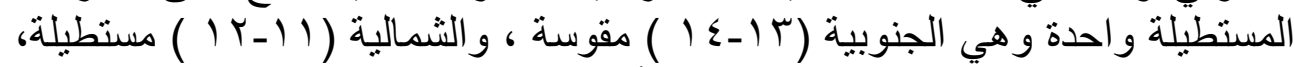

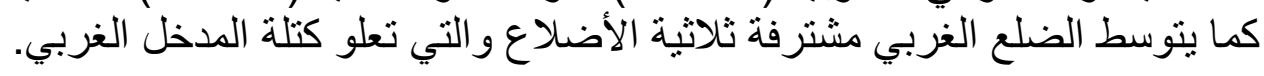

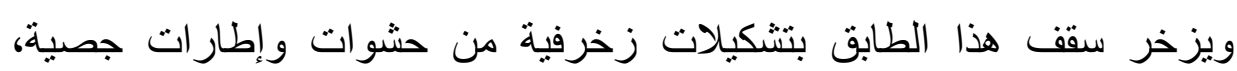
عبارة عن صرر مركزية وسطى يحيط بهاب إطار ات مستطيلة من كيز ونئ وان صنوبر 


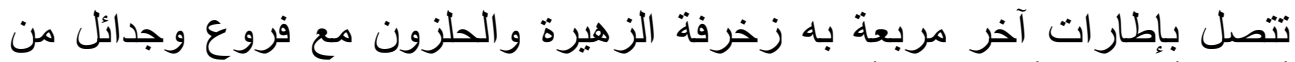

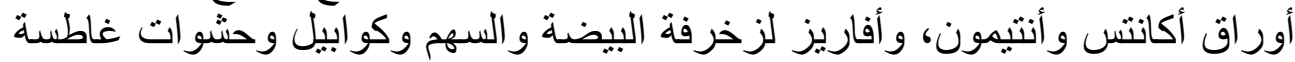

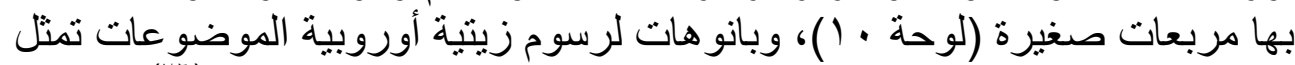

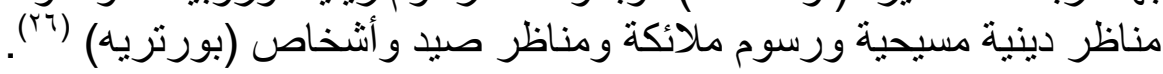
العناصر القنية ومقتنيات القصر: بصفة عامة فقد غطيت أرضية طوابق القصر

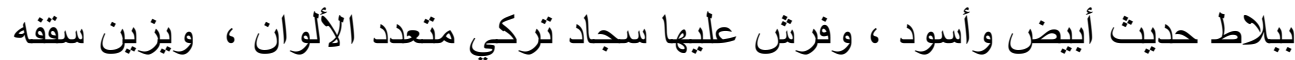

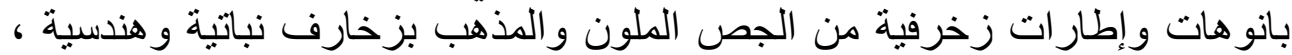

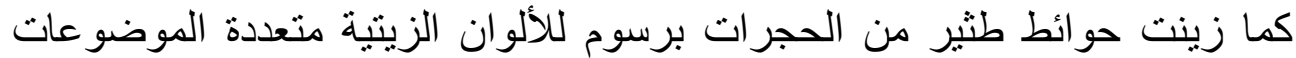

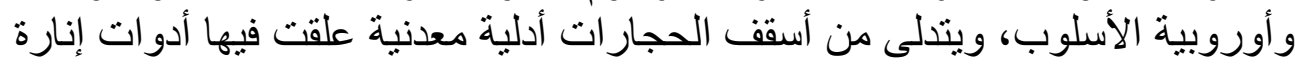

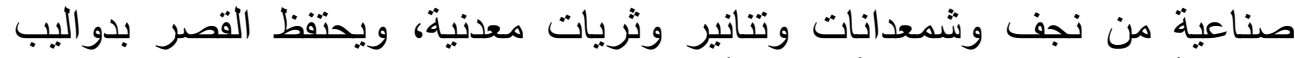

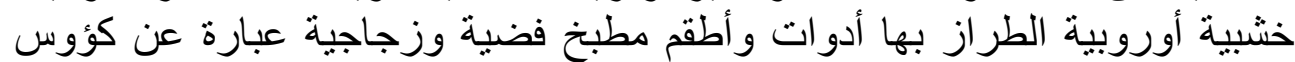

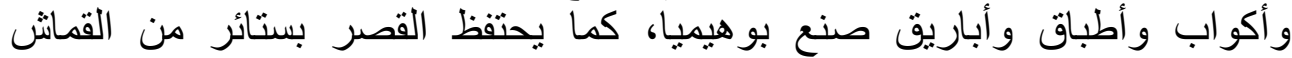

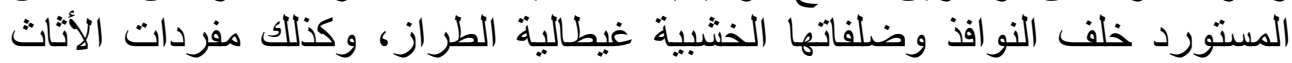

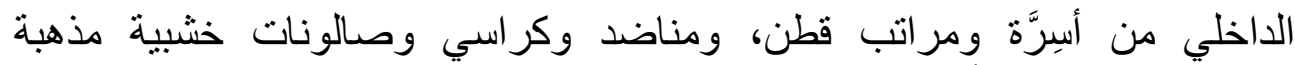

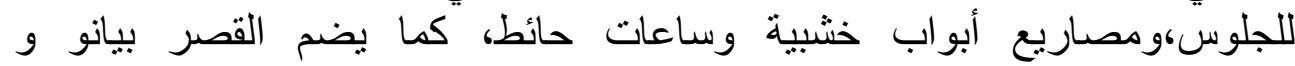

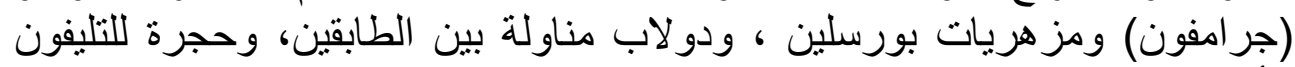

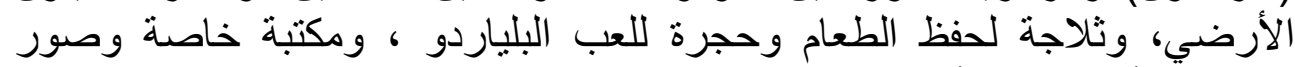
شخصية لأفر اد عائلة ألكسان باشنا.

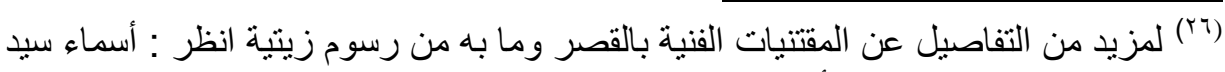

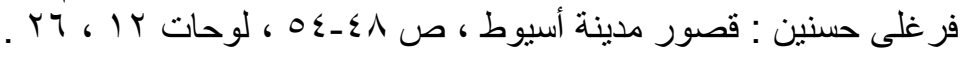




\section{تحليل الطراز المعماري والإنشائي للمبنى:}

يصنف القصر موضع الدراسة - ضمن العمائر المدنية في مدينة أسيوط وفي مصر الإنسر

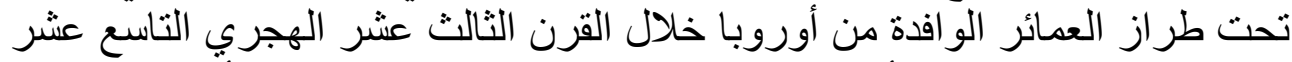

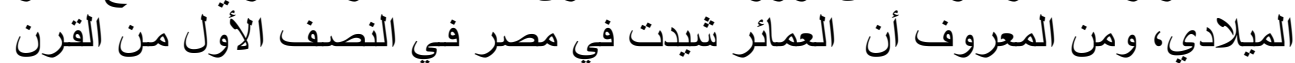

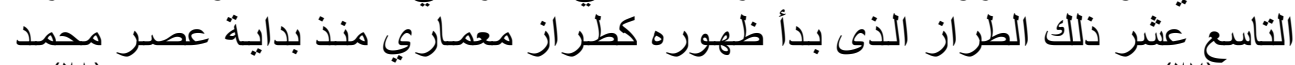

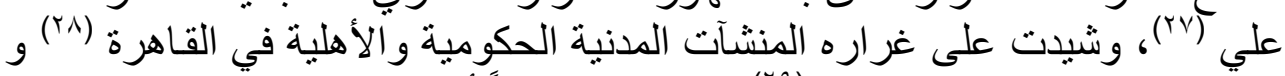

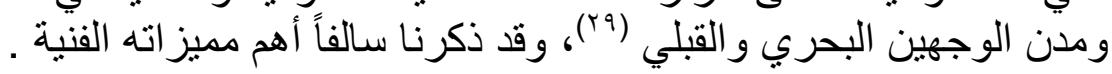

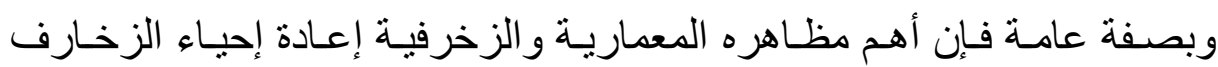

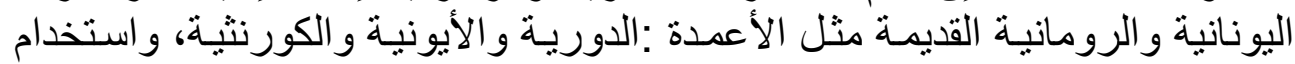

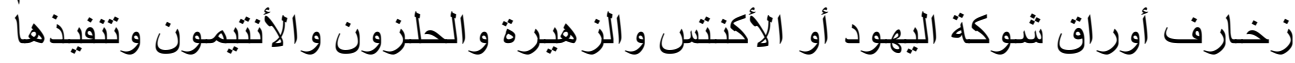

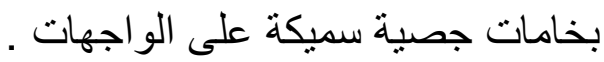

تحليل عناصر القصر :

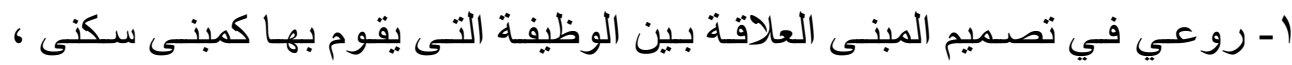

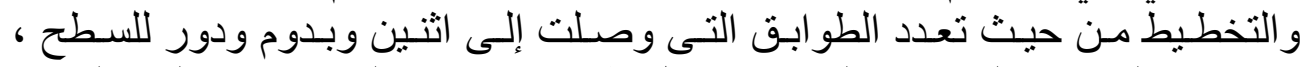

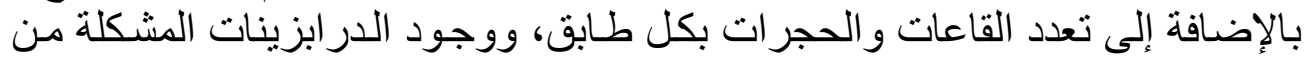

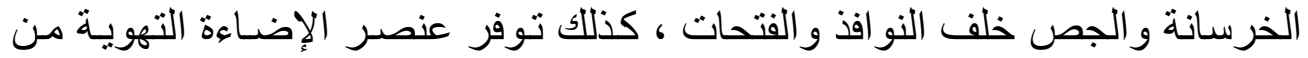

ماكلة (rV)

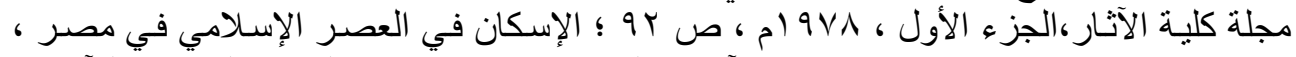

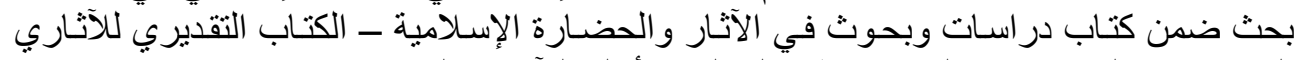

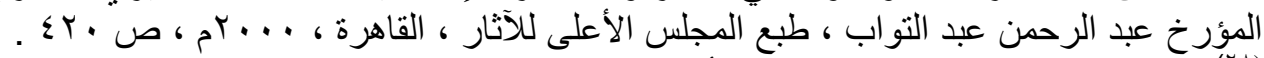

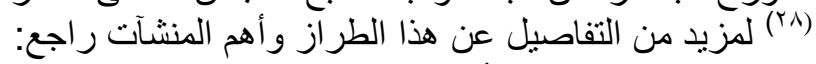

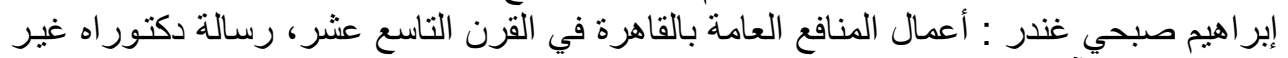

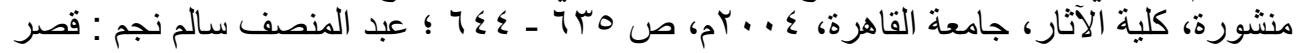

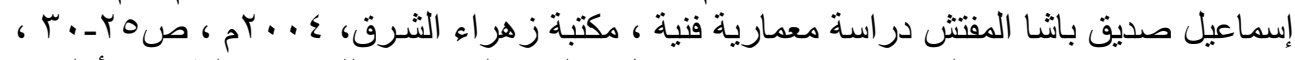

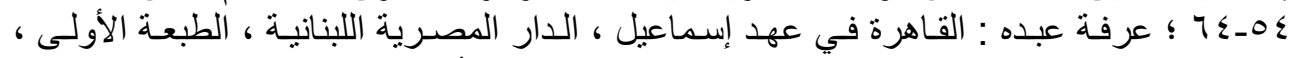

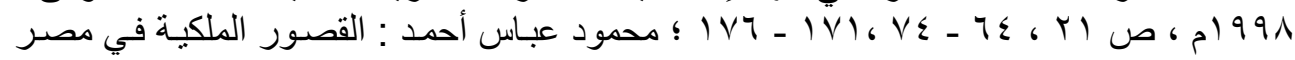

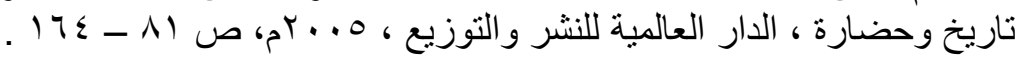
Jacob Burckhardt, The Civilization of the Renaissance, , p-p.104 - 69, p.353, 255,358,359,382,383.

Nihal . Tamraz, Nineteenth - Century Carien Houses and Palaces ,pp. 36-39; Cynthia Myntti , Paris Along the Nile, pp.13-5, 92-105.

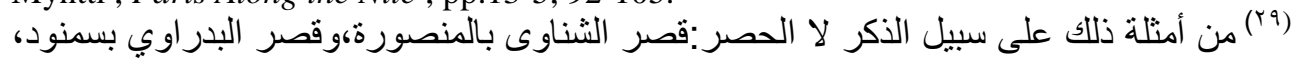

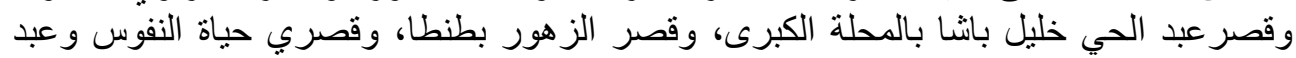

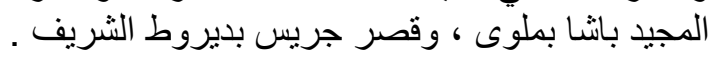


خلال تعدد الفتحات ، فضلاً عن استخدام مو اد خام ممثلة في أنواع معينة من الرخام

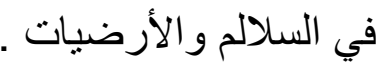

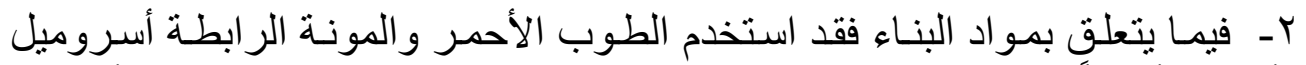

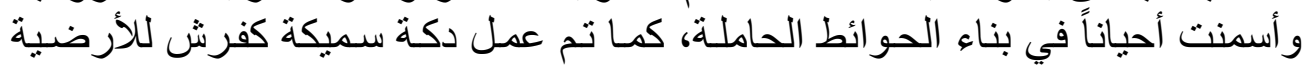

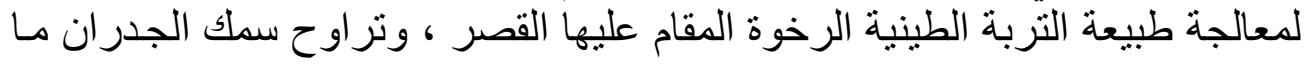

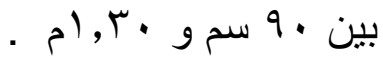

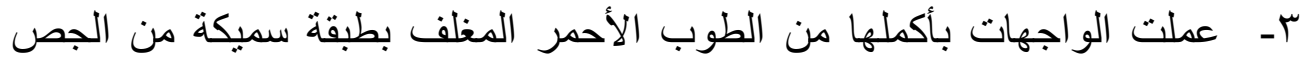

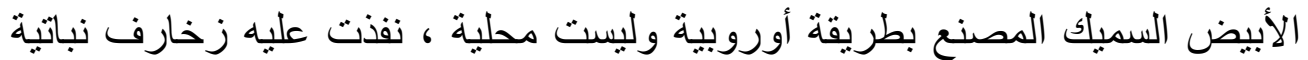

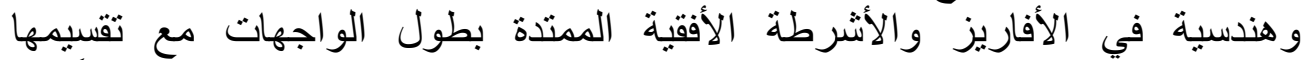

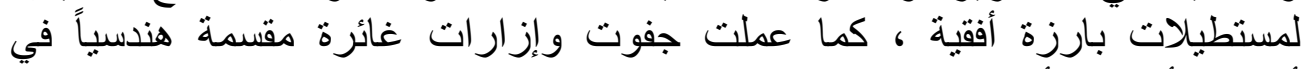
أوضاع أفقية ور أسية لإحداث أنتويع في الزخارف على التى مسطح الو اجهات بالكامل

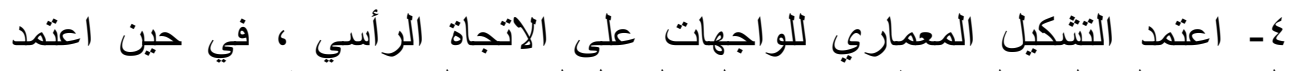

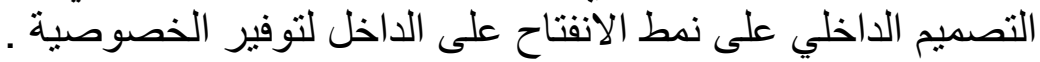

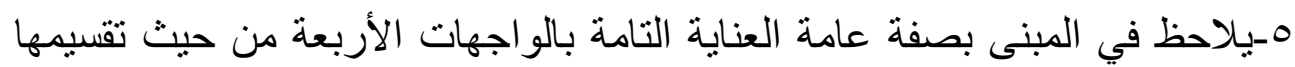

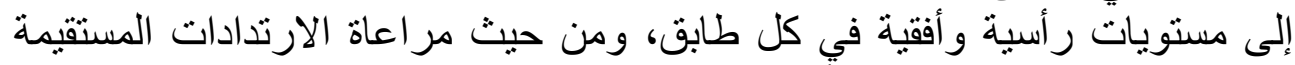

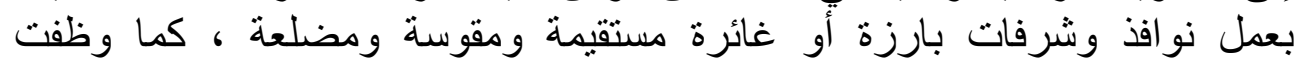
التشكيلات الزخرفية بكثرة سواء الهندسية أو النباتية ، وأحياناً الزخارف الآدية وكية و الحيو انية .

T- تميز موقع القصر بالعبقرية لوقوعه على النيل مباثرة مع توظيف اتجاه

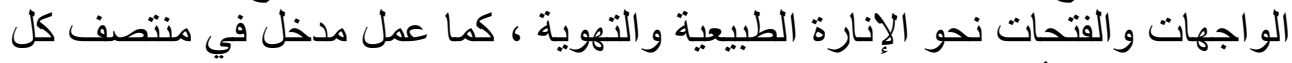

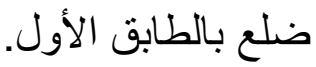




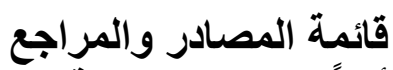
أولاً المصادر المعرادر والمبية:

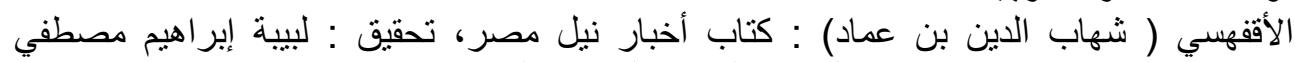

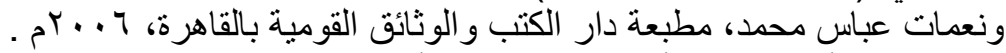

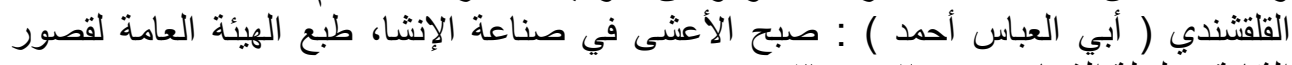

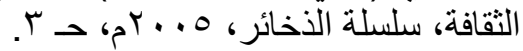

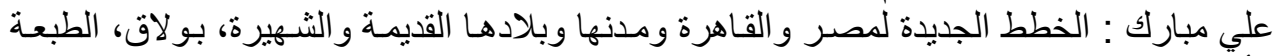

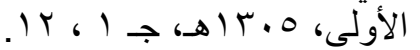

$$
\begin{aligned}
& \text { ثانياً المراجع العربية }
\end{aligned}
$$

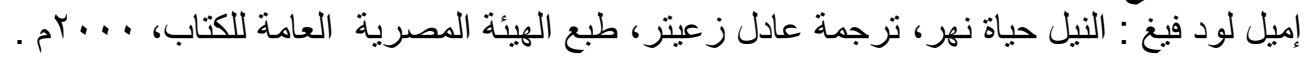

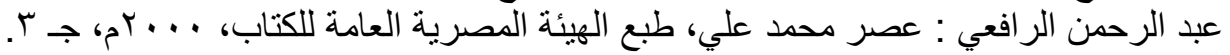

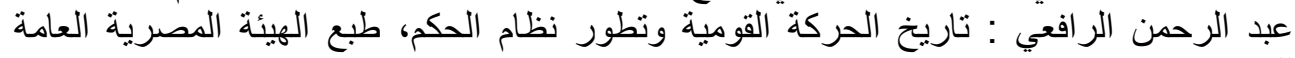

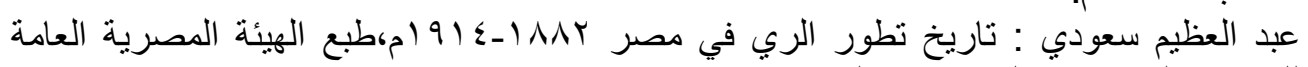

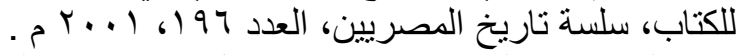

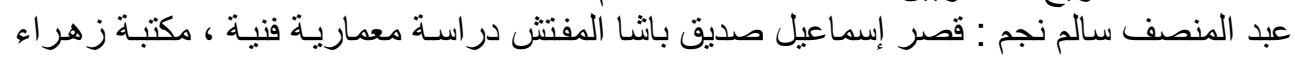

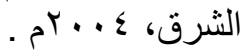

عثمان فيض الله : مدينة أسيوط بحث في بيئتها بين الماضي و الحاضر ، أسبوط، مطبعة الجهاد.

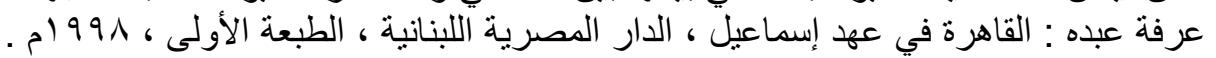

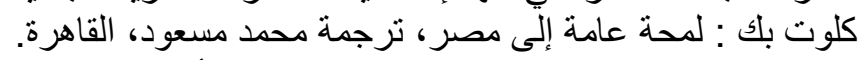

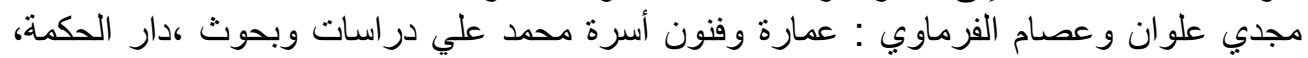

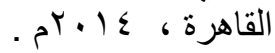
محمد رمزي : القاموس الجغر افي للبلاد المصرية، طبع الهيئة المصرية العامـة للكتاب، القاهرة،

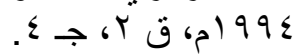

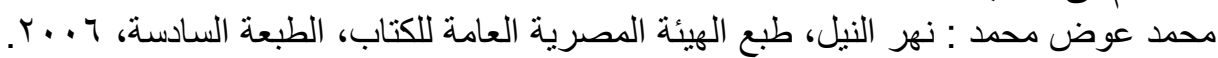

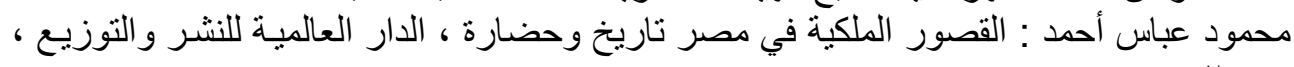

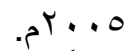
ثالثاً الدوريات العربة العبية

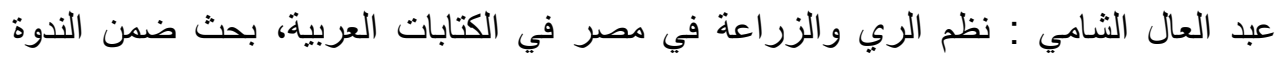

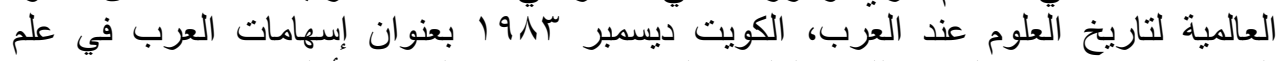

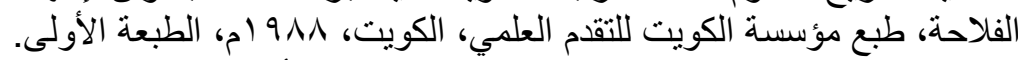

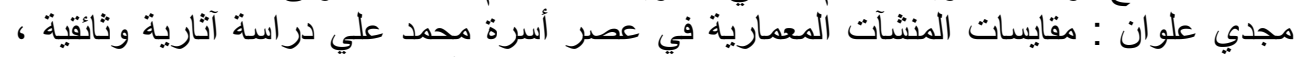

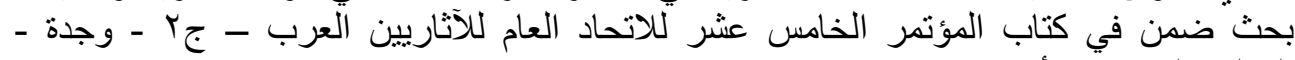

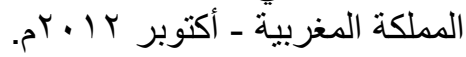

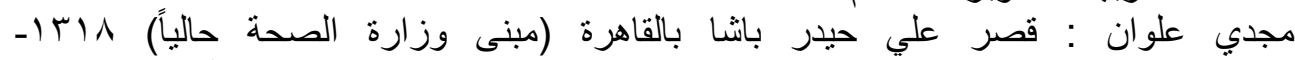

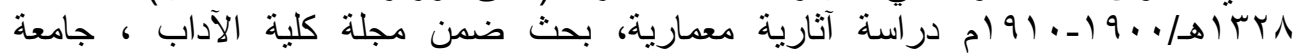

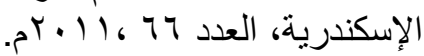

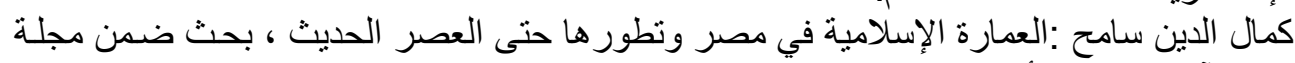

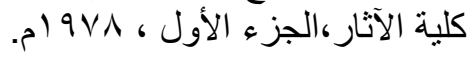




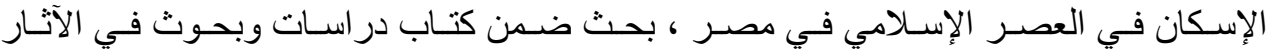

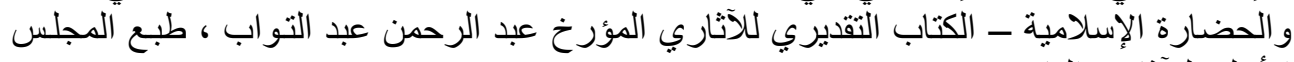

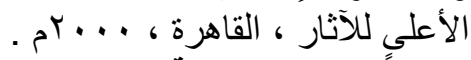

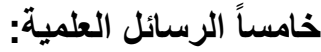

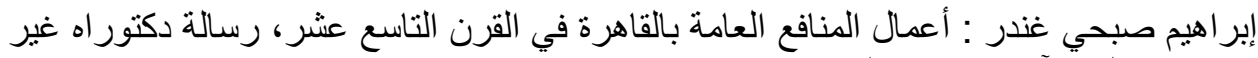

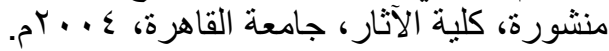

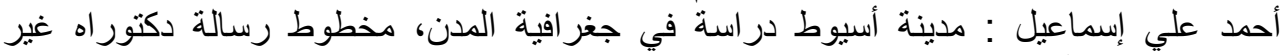

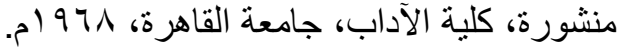

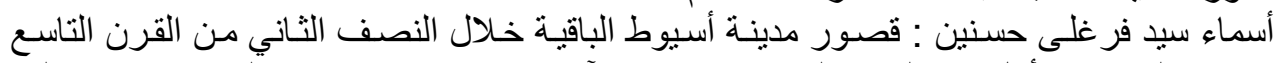

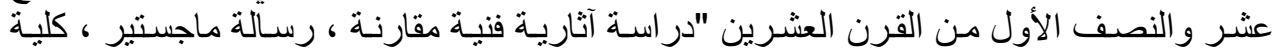

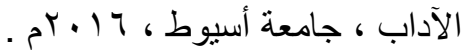

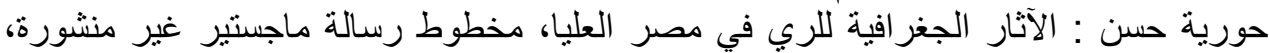

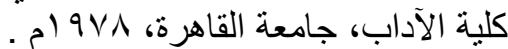

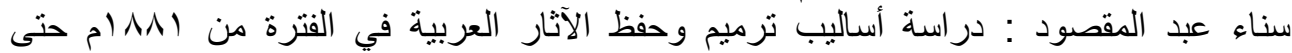

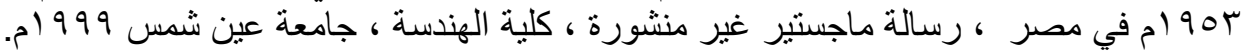

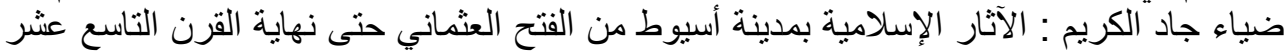

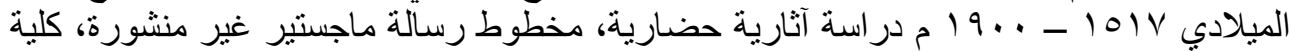

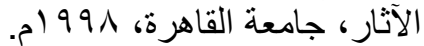

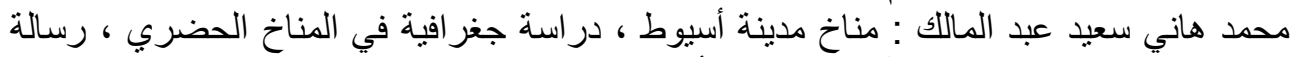

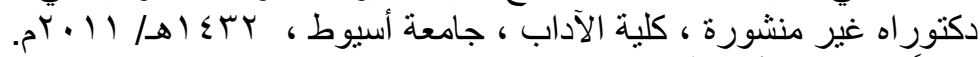

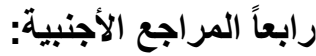

Cynthia Myntti, Paris Along the Nile- Architecture in Cairo from the Belle Époque, The American University in Cairo Press, 1999.

Helen Anne B.Rivlin., The Agricultural Police of Muhammad Ali in Egypt, Harvard University Press, 1961.

Jacob Burckhardt, The Civilization of the Renaissance, Oxford University Press, 1945.

Mahmoud EL-Gowhary, EX-Royal Palaces in Egypt from Mohamed Aly to Farouk, dar al-maaref,1954.

Nihal. Tamraz , Nineteenth - Century Carien Houses and Palaces ,The American University in Cairo Press, 1994.

Volait ,Mercedes, Ambroise Baudry, L 'Egypt d 'un Architecte, Paris :Gallimard ,1998. 


\section{الأشكال و واللوحات}
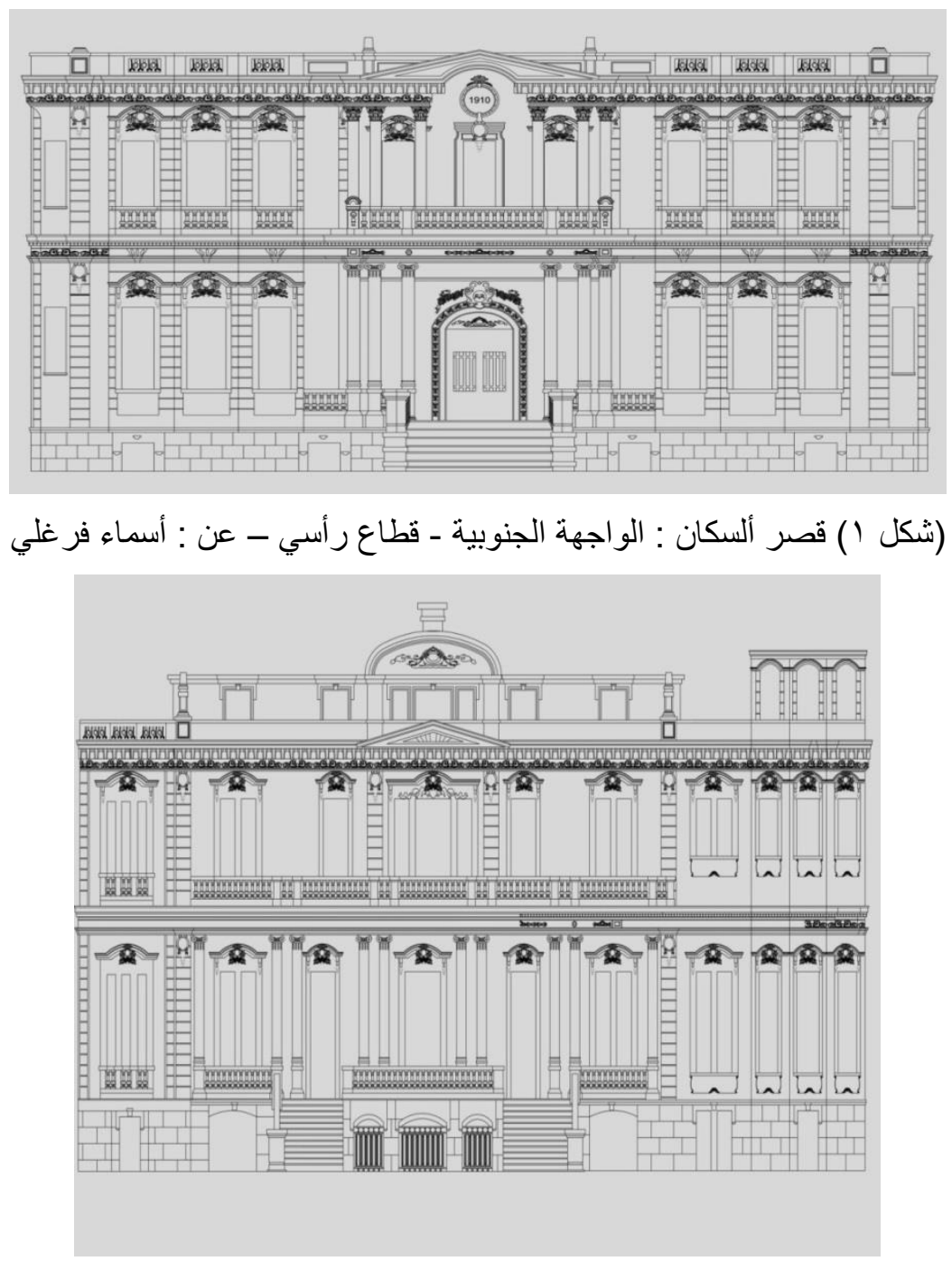

(شكل r) قصر ألسكان : الواجهة الشرقية ـ قطاع رأسي - عن : أسماء فرغلي 


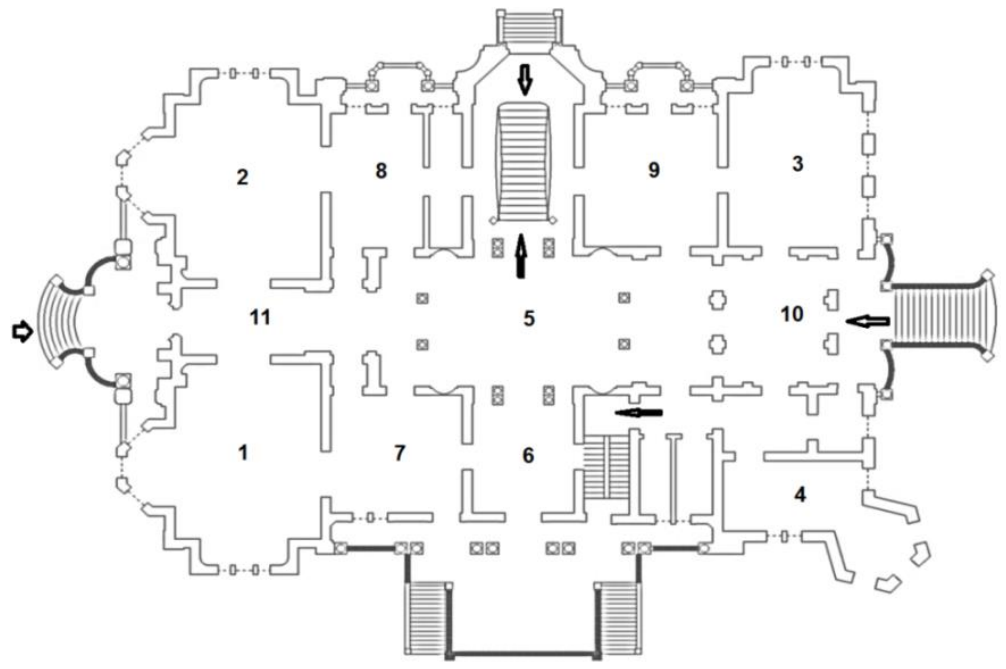

(شكل) قصر ألسكان:الطابق الأول مسقط أفقي عن: أسماء فرغلي مع تعديلات من عمل الباحث

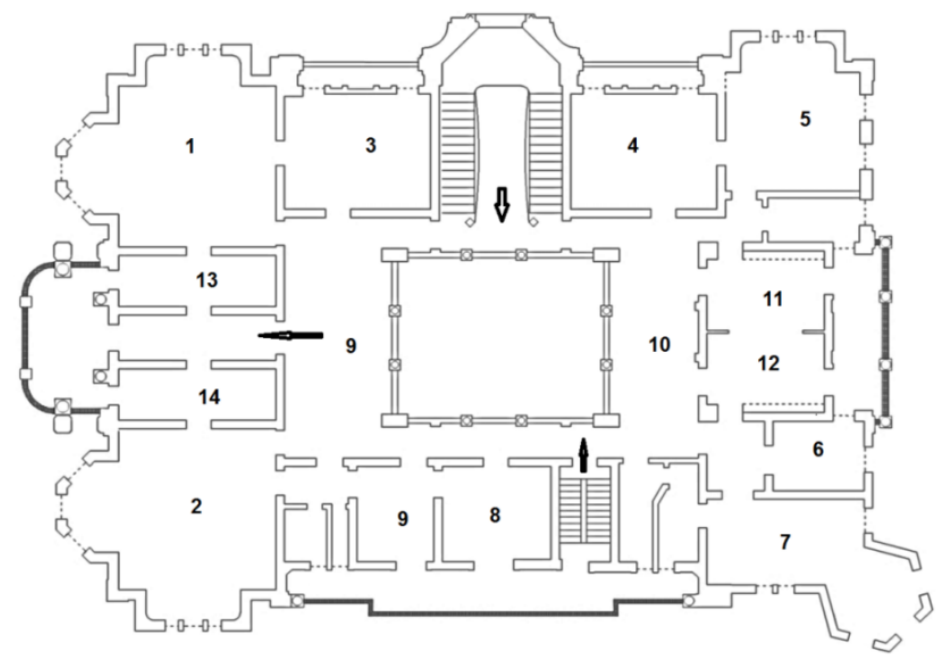

(شكل ع ) قصر ألسكان : الطاابق الثاني - مسقط أفقي- عن : أسماء فرغلي مع تعديلات من عمل 
دراسات في آثار الوطن العربي مج T

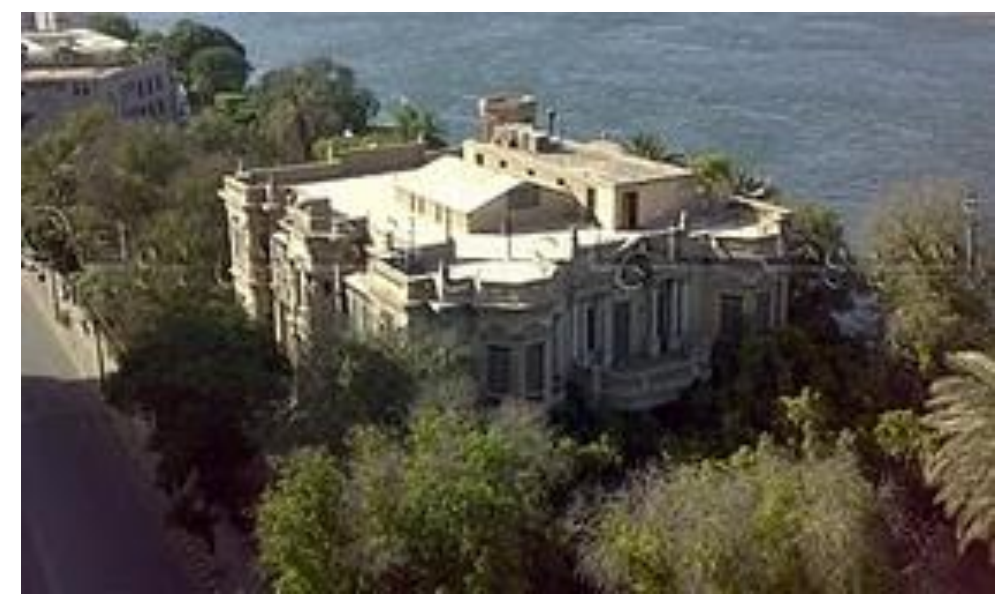

(لوحة () قصر ألسكان : منظر عام يبين الموقع على النيل

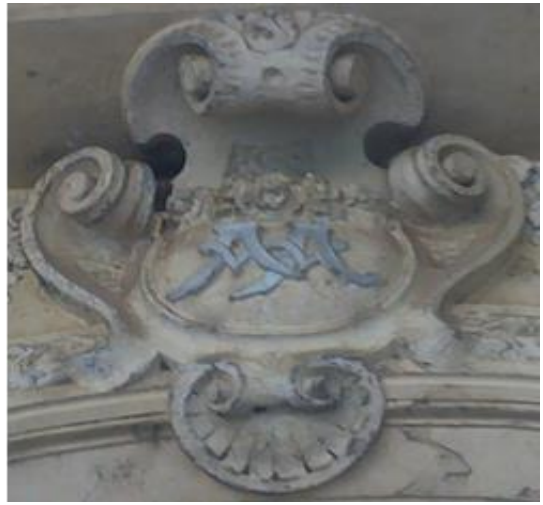

(لوحةץ) قصر السكان :مونجر ام المنشىء

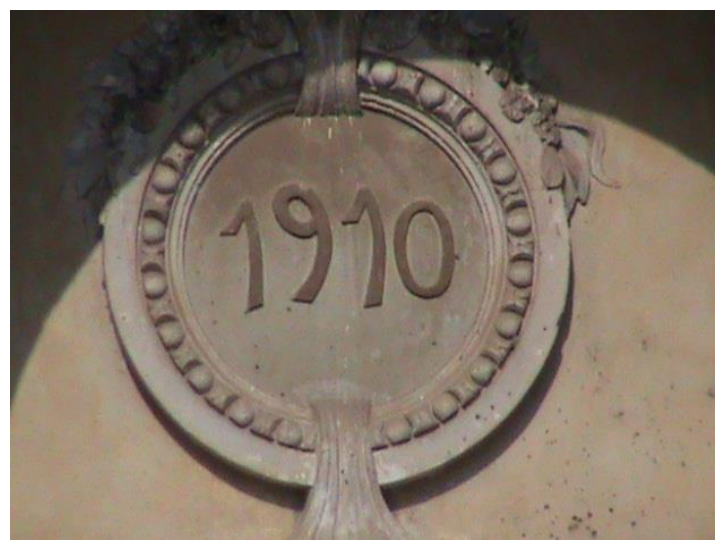

(لوحة ץ) قصر ألكسان: تاريخ الإنشاء بالأرقام 
دراسات في آثار الوطن العربي م.

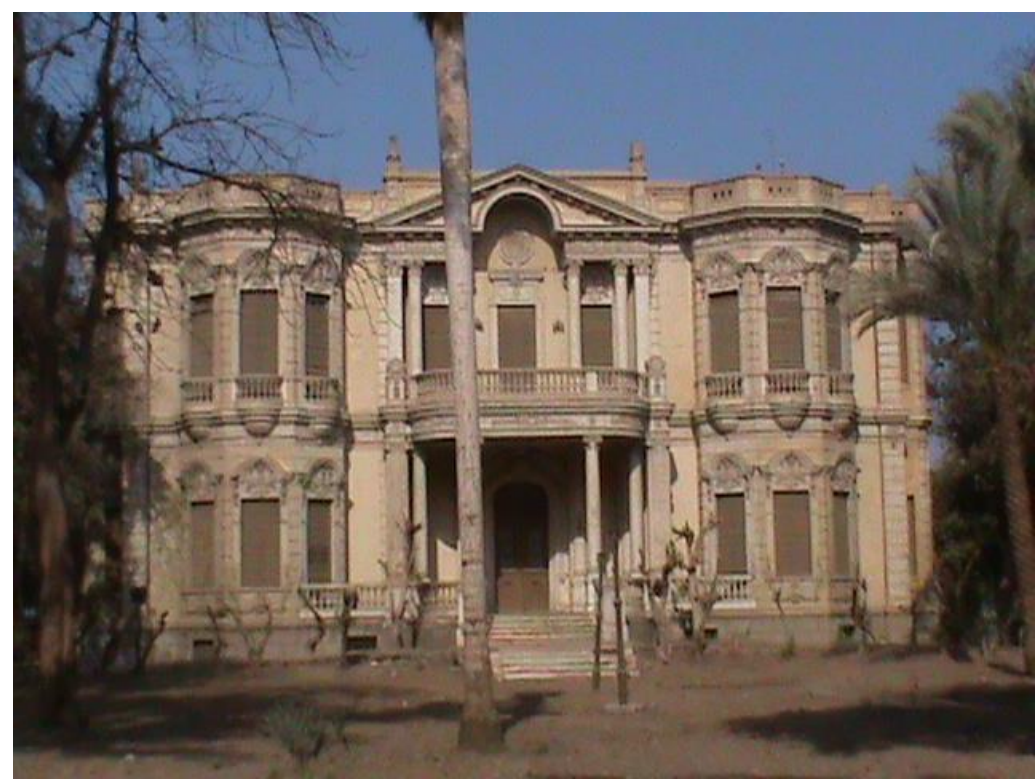

(لوحة ؟) قصر ألسكان : الواجهة الجنوبية

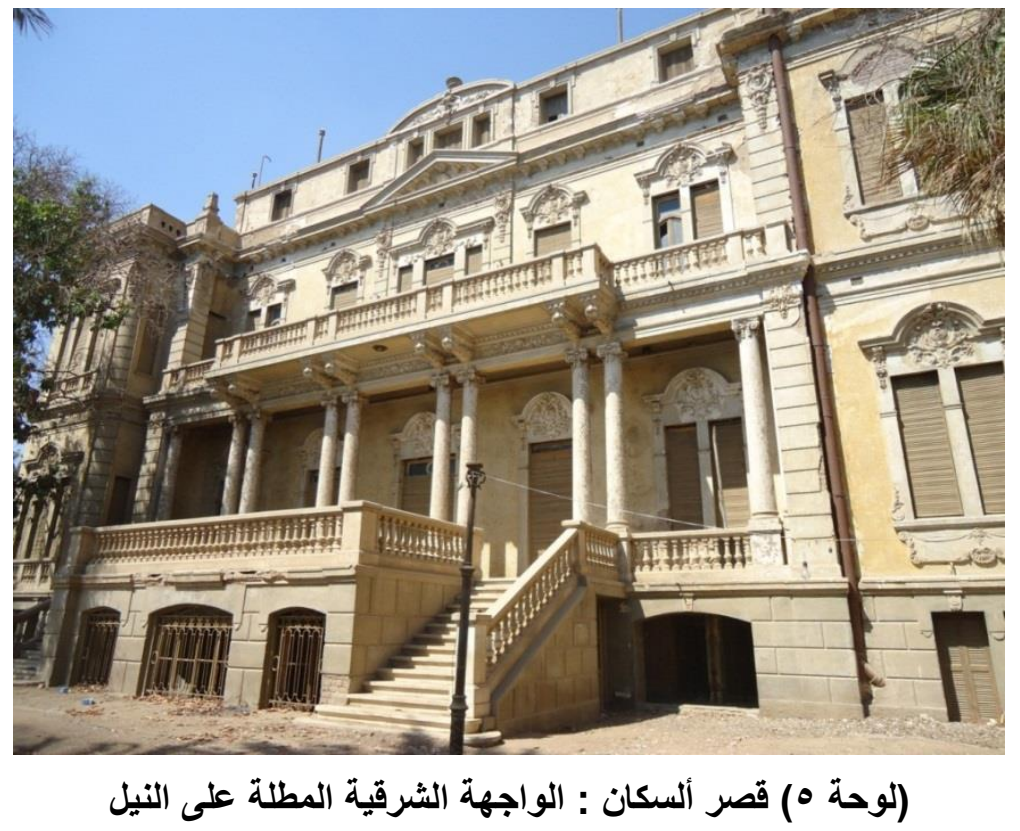




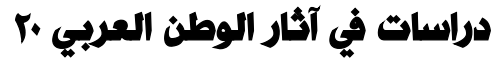

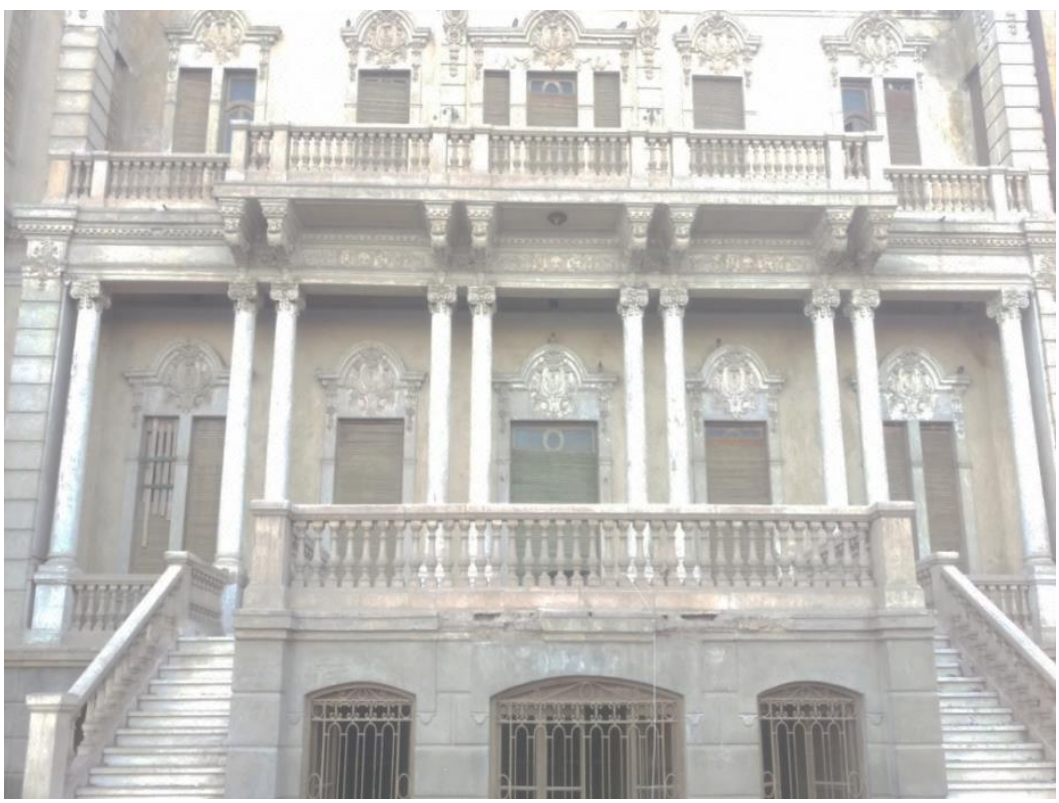

(لوحة ؟) قصر ألسكان : الدرج ذي المطلعين وتقسيم الثرفات والنو افذ بالو اجهة الثرقية

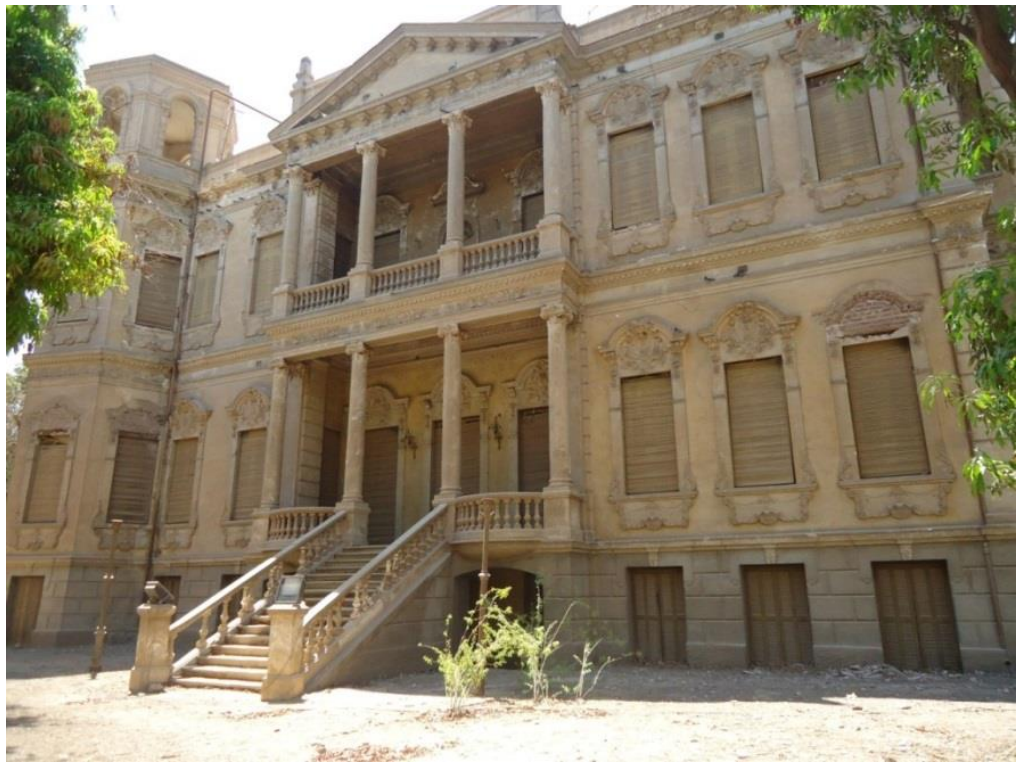

(لوحة V) قصر ألسكان : الواجهة الثمالية المطلة على النيل 


\section{دراسات في آثار الوطن العربي مr}
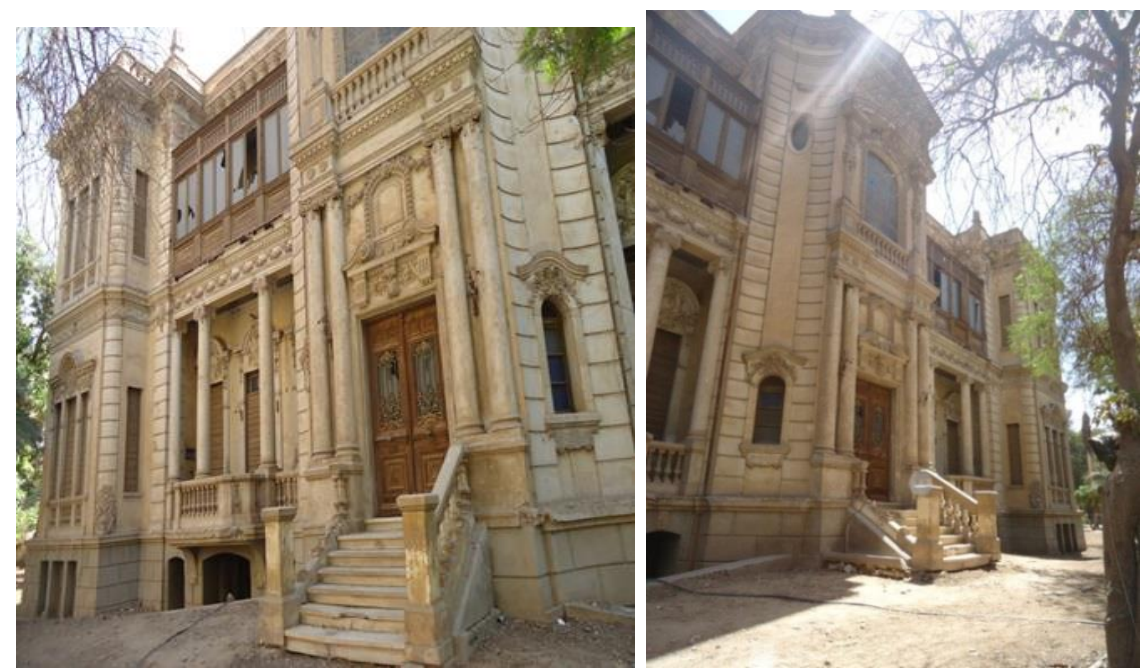

(لوحة ^) قصر ألسكان : أقسام الواجهة الغربية المطلة على شارع المحافظة

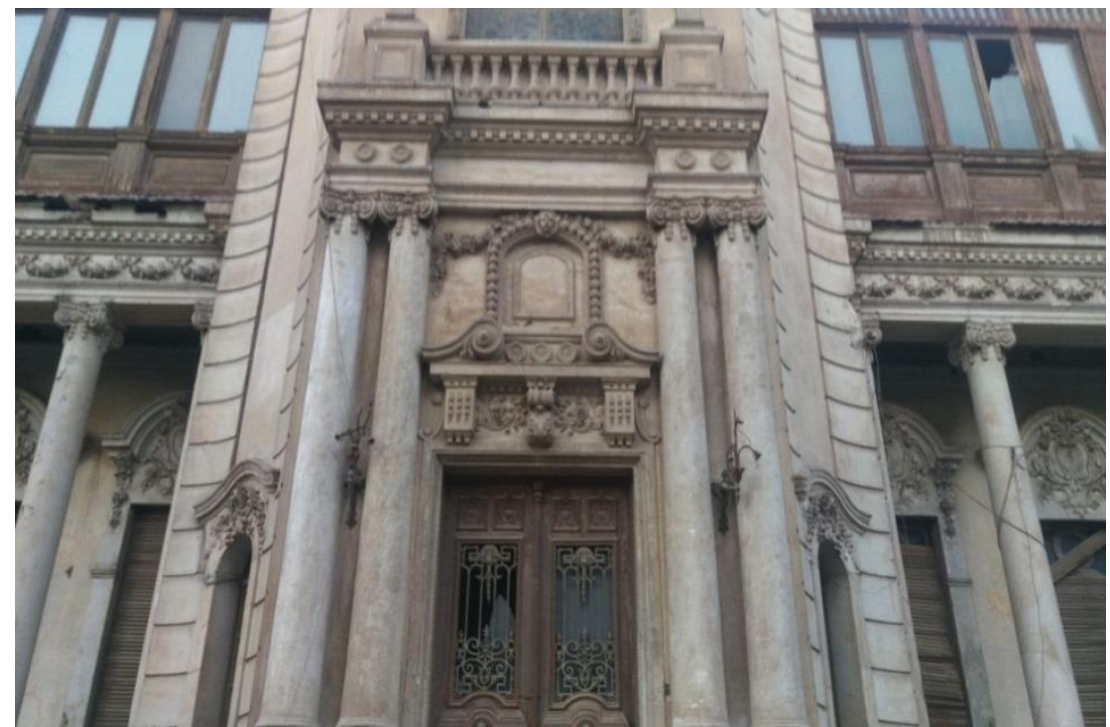

(لوحة 9) قصر ألسكان : تفاصيل كتلة مدخل الو اجهة الغربية المطلة على شار ع المحافظة 
Pراسات في آثار الوطن العربي r.

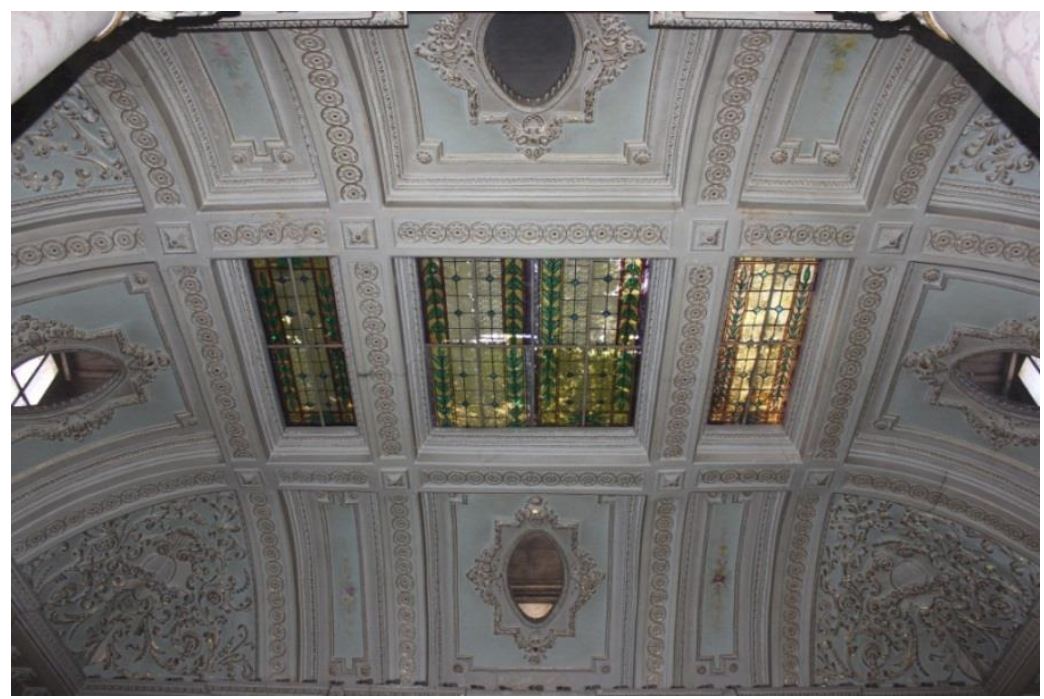

(لوحة • () قصر ألسكان : سق الصالة الوسطى بالطابق الأول

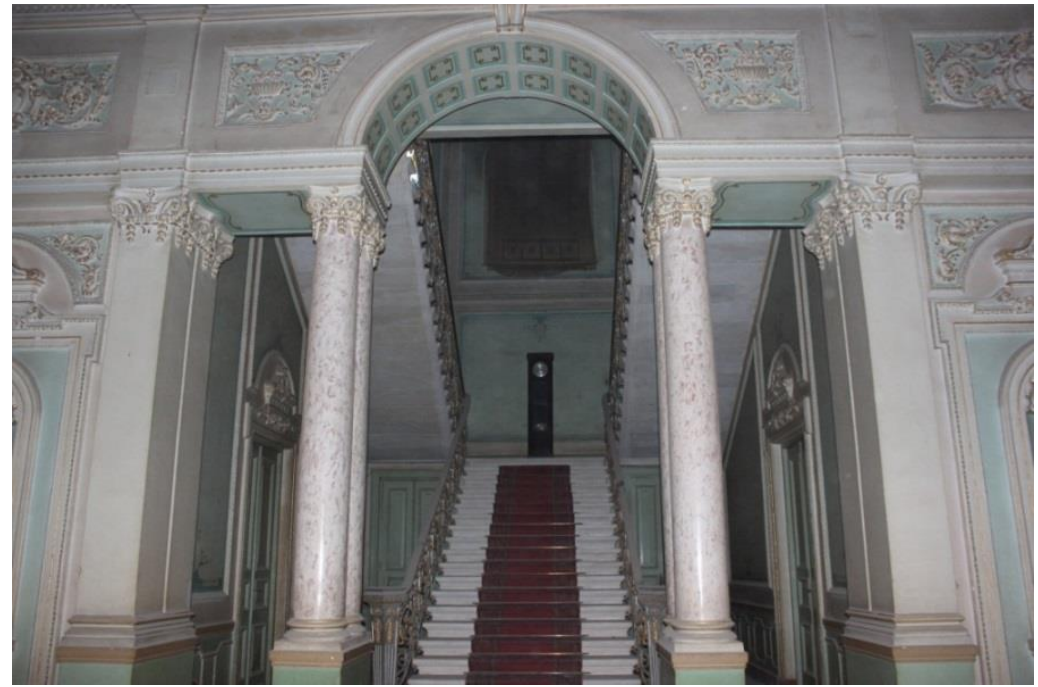

(لوحة ( () السلم الصاعد بالجهة الغربية و بائكة بالصالة الوسطى بالطابق الأول 


\section{The Palace of Alexan in Assiut Archaeological and Architectural study Magdy Abd-Algwad Elwan Osman}

\section{Abstract:}

The construction of many palaces of different Architectural and Artistic styles during the reign of Mohammed Ali's family in Egypt spread. Most of these Architectural and Artistic styles were derived from Europe from the 16th century until the 18th century, in the era of Mohamed Ali most European Architectural and Artistic trends appeared in the palaces of Egypt, especially the cities of Cairo and Alexandria, These European architectural styles moved to the regions of Egypt and its cities.

This study deals with the study of Architectural and Artistic features in Assiut palaces, applying to Alexan Palace, one of many survived palaces in the same city, The researcher will study this subject

through three axes:

1- Descriptive Study of Alexan Palace.

2- The features of the local Architecture.

3- The Technical features of the original of the Palace.

The research will be equipped with a number of plans and photographic plates to enrich the scientific study.

Keywords:Assiut - Palace - Renaissance style - Baroque Gothic style - Monogram- Alexan.

'Professor of Islamic Architecture-Head of the department of Archaeology- Assiut University $\underline{\mathrm{dr} \text { art_aaa@yahoo.com }}$ 